\title{
Tidal flat deposits of the Lower Proterozoic Campbell Group along the southwestern margin of the Kaapvaal Craton, Northern Cape Province, South Africa
}

\author{
W. AltermanN* and H.-G. Herbig** \\ *Institut für Allgemeine und Angewandte Geologie, Ludwig-Maximilians-Universität München, \\ Luisenstraße 37, D-8000 München 2, Germany \\ *Institut für Geologie, Freie Universităt Berlin, Altensteinstraße 34a, D-1000 Berlin 33, Germany
}

(Accepted for publication 28th August, 1990)

\begin{abstract}
Lower Proterozoic stromatolites and associated clastic carbonate deposits of the Campbell Group, from the southem margin (Prieska area) of the Kaapvaal Craton, northem Cape Province, are described. Contrary to previous interpretations (Beukes, 1978; 1980a) shallow subtidal to supratidal facies are recognised and discussed in regional context. An altemative model for the facies development of the Campbell Group is proposed.
\end{abstract}

\section{INTRODUCTION}

The stromatolitic assemblages and associated sedimentary facies from the Lower Proterozoic Campbell Group of the northern Cape Province and of the Chuniespoort Group in Transvaal are described in many publications. Almost all of the descriptions concentrate on outcrop located in Transvaal and in the northern part of Griqualand West (Young, 1932; 1934; 1935; 1940 Eriksson, 1977; Eriksson and Truswell, 1973; 1974; Eriksson et al., 1976. Truswell and Eriksson, 1972; 1973 , and many others). These outcrops obviously caught the attention of investigators because of the stromatolites. In contrast, in the southwesternmost outcrop of the Campbell Group the situation is different. Owing to multiple folding and thrusting (Altermann and Halbich, 1990) the outcrop condition in the Prieska region (Fig. 1) do not allow good lateral facies correlations. The primary structures are obliterated by thorough recrystallization and the stratigraphy of the units is largely disturbed by tectonic overprint. However, in the interpretation of the Campbell sedimentary basin these outcrops play a key role, as the development of turbiditic basinal facies within the Campbell carbonates is claimed for the region south of the Griquatown Fault (Beukes, 1980b; 1983). In this paper we present new information on the sedimentary facies and associated stromatolites from outcrops along the Orange River, 1.e. from the southwestern margin of the Campbell Group outcrops in the northern Cape Province (Fig. 1).

\section{GEOLOGICAL SETTING}

Sedimentation of the Transvaal Supergroup on the Kaapvaal Craton started with the Vryburg Silstone Formation (SACS, 1980) consisting of shales, quartzites, siltstones and subordinate volcanics. These rocks rest unconformably on the 2700 Ma old (Armstrong et al, 1986) volcanic Ventersdorp Supergroup. The Vryburg Formation is conformably overlain by the Campell Group consisting of the lower Schmidtsdrif Formation and the Ghaap Plateau Dolomite Formation. The latter is in turn conformably overlain by the Asbestos Hills Banded Ironstone Formation of the Griquatown Group (consisting of Kuruman and Griquatown Iron Formations and hereafter referred to as BIF). The minimum age of the BIF is generally considered to be $2240 \mathrm{Ma}$, as this age was obtained from the Ongeluk Andesite Formation (Walraven et al., 1982) which unconformably overlies the BIF. Recently a preliminary age of $2500 \mathrm{Ma}$ was determined for the volcaniclastic intercalations in the BIF (Armstrong, pers. communication, 1989). According to this data, deposition of the Campbell Group should occupy the time span between the uppermost Archean and lowermost Proterozolc.

While the thickness of the Vryburg Formation remains constant between 75 and 100 metres, the thickness of the Campbell Group increases considerably from south to north. The Schmidtsdrif Formation is between 3 and 275 metres and the Ghaap Plateau Formation between 900 and 1600 metres thick, respectively (SACS, 1980). 


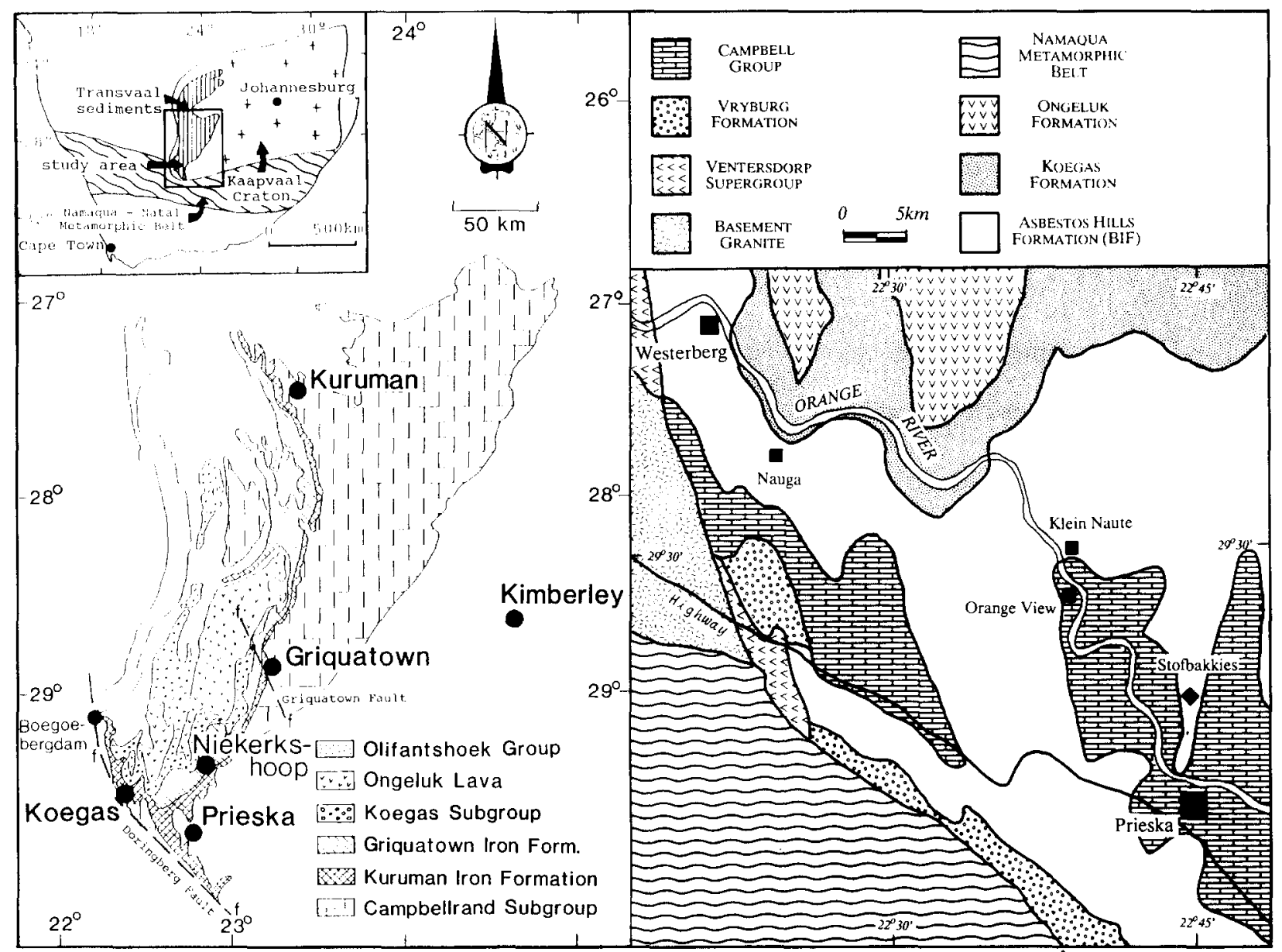

Fig. 1. Geological setting and location of study area.

\section{PREVIOUS WORK}

The transition of the siliciclastic to carbonate sedimentation in the Campbell Group was described by Visser and Grobler (1972). These authors identified several interlayered siliciclastic and carbonate facies in the area northeast of Schmidtsdrif, along the escarpment bordering the Vaal River. They ascribed the mixed facies development to transgresstve phases on tidal flats and proposed to give these transitional beds formation rank (Schmidtsdrif Formation), which was accepted by SACS (1980). From the shape of the stromatolite bioherms and from paleocurrent directions (NE-SW) Visser and Grobler (1972), concluded that "open ocean" bordered the tidal flats on the northeastern side, thus implying that the land must have lain to the southwest.

Beukes, 1977 gave detalled facies description and interpretation of the transitional strata between the Black Reef Formation (Vryburg Silstone Formation of SACS, 1980) and the Schmidtsdrift Formation (Schmidtsdrif of SACS, 1980) from an area situated some $150 \mathrm{~km}$ north of Schmidtsdrif.
According to Beukes (1977), the transition between the two formations takes place through a number of siliciclastic, fining-upward cycles followed by mixed siliciclastic/carbonate cycles (argillite - quartz arenite - dolarenite - cryptalgal dolomite) and eventually by carbonate cycles (oolitic dolomite - cryptalgal dolomite - dolomitic arenite). The siliciclastic cycles represent subtidal to tidal flat deposits connected to open sea. The mixed cycles represent transgressive tidal flat deposits (clastics) and prograding carbonate subtidal - tidal flat deposits (dolarenite - cryptalgal dolomite). The sedimentation mechanism is explained in terms of rapid transgressions which led to silicicastic sedimentation, followed by stabilization of sea level and development of carbonates on prograding tidal flats. These tidal flats were submerged during repeated transgression, but were succeeded by conditions which favoured carbonate deposition. The NE-SW palaeocurrent directions measured by Beukes (1977), are in agreement with those of Visser and Grobler (1972).

The stromatolites and sedimentary facies of the Ghaap Plateau Formation were first described by 
Young (1928) and by Young and Mendelssohn (1948). Young (1928) initially ascribed the stromatolitic structures in the Campbell Rand Dolomites to pressure phenomena, but in a later serles of papers, Young $(1932 ; 1933 ; 1934 ; 1940 ; 1945)$, recognised the bio-sedimentary origin of these structures.

Truswell and Eriksson (1973) investigated the basal beds of the Campbell Group at the Campbell Rand escarpment, some $50 \mathrm{~km}$ north of the locality described by Visser and Grobler (1972) and 100 $\mathrm{km}$ south of the locality described by Beukes (1977). In 160 metres of nearly continuous section. Truswell and Eriksson (1973) distinguished four main facies variations:

dome-shaped stromatolites of varying size and relief; columnar stromatolites of various sizes. including branched, tabular and domal forms; spheroidal forms which are not always of clearly organic origin and are commonly associated with tabular masses and rarely with domes and columns. Breccia fragments and ripple marks are mentioned within this facies; low-relief, crinkled and (rarely) laminated stromatolites.

From these stromatolitic facies and the associated sedimentary structures a tidal flat model was developed by Truswell and Eriksson (1973). This concept leans strongly on Irwin's (1965) carbonate shelf model and Logan's (1961) observation that dome-shaped stromatolites increase in size and relief with depth of water in the intertidal zone. Furthermore, the authors extended their concept into the subtidal regime occupied by giant domes (up to 10 by 40 metres in plan and 13 metres high). In the measured 160 metres section transgressive and regressive cycles within the supratidal to subtidal range were recognised. From the eastwest elongation of the stromatolite domes, Truswell and Eriksson, 1973 concluded that the tidal currents flowed normal to the approximately north-south trending shoreline.

Beukes (1978) investigated the facies of the Campbell Group over the entire norther Cape Province (Fig. 1). He distinguished 10 major lithofacies which were subdivided into several subfacies. The major lithofacies are:

1) quartz arenite; 2) argillite; 3) clastic-algal laminated carbonates; 4) columnar-stromatolitic dolostones and limestones; 5) giant domal dolostones and limestones; 6) domal dolostones and limestones; 7) dolostones and limestones with disturbed algal mats and fenestral fabrics: 8) arenitic carbonates; 9) brecciated carbonates; 10) chert.

Furthermore, Beukes (1978) mapped out several stratigraphic formations within the Ghaap Group and distinguished between two main facies types:

the Ghaap Plateau facies in the basin interior; the Prieska facies along the south-western basin margin.

According to Beukes (1978) the Ghaap Plateau facies only occurs in the areas north of the Griquatown Fault Zone, while the Prieska facies is restricted to Beukes' (1978) Nouga Formation, which represents the entire carbonate Ghaap Group south of the Griquatown Fault Zone. North of this fault zone, the Prieska facies is represented by the Monteville Formation at the base and by the Gamohaan Formation at the top of the Ghaap Group. Both formations pass laterally into the Nouga Formation (Fig. 12).

Since the detailed description of the Prieska facies was published only in Afrikaans (Beukes, 1978; 1980a) and the later description Beukes, 1987 differed from the earlier papers, we feel that discussion of this description is necessary to understand the problems in Beukes' later (1983: 1986; 1987; 1989) Interpretations of the Prieska facies, and of the entire depositional basin of the Ghaap Plateau carbonates.

Beukes (1978) presented type sections for both facies and described the Prieska facies as consisting exclusively of his lithofacies 3 (clastic - algal laminated carbonates) and 7 (dolostones and limestones with disturbed algal mats and fenestral fabrics). Later Beukes (1987) described Conophyton stromatolites in the Prieska facies. Beukes (1980a) specified facies 3 as a horizontally laminated facies that does not contain any domal stromatolites. As in his 1978 thesis, Beukes (1980a) subdivided this lithofacies into subfacies of sapropelic carbonate mud occurring together with microlaminated algal mats and massively laminated clastic carbonates, as well as clastic laminated dolomites and limestones and Fe-rich dolomites and limestones. The facies of fenestral fabrics and SH-I algal structures (subfacies of Beukes', 1978 facles 7) was described as being best developed in the Gamohaan Formation, 1.e. the uppermost formation of the Ghaap Group, and less well developed in the Nouga and Monteville Formations. The Ghaap Plateau facies (Reivilo, Fairfield, Klippan, and Kogelbeen Formations) was described as consisting of facies 2-10. It seems clear from Beukes' (1978) description and from the application of the facies concept of Truswell and Eriksson (1973) that the Ghaap Plateau facies consists of several shallowing-upward (regressive) cycles each followed by a transgression (Fig. 12). The cycles usually start with various domal stromatolites or glant domal bioherms (facies 6 and 5) and pass upwards into columnar stromatolites, flat-laminated algal mats with fenestral fabrics and SH-I structures, clastic carbonates, and cherts. This interpretation was suggested by Beukes (1978; 1987), where the Ghaap Plateau facies is described as carbonate platform facies. 
The Prieska facies, in which no domal stromatolites are present (Beukes, 1978) and which comprises clastic-algal laminated carbonates, Fe-rich banded cherts, SH-I structured algal mats, and algal laminites with fenestral fabrics, must be interpreted as low energy tidal flat and supratidal environments. However, this facies is interpreted in Beukes' (1978) thesis as basin facies consisting of pelagic muds, euxinic facies (based on pyrite abundance) and intercalated layers of turbiditic origin, showing graded bedding.

Later, Beukes (1980b; 1983; 1987) classified the Prieska facies variously as "endoclastic basinal" facles, "carbonate turbidites with Fe-dolomite, chert and basic tuffs", "pyritic carbonaceous shale of euxinic basin" and "ankerite banded chert at the transition between euxinic basin and deep shelf" environment (Beukes, 1983; Fig. 4-7, pp. 153154). Although a carbonate turbiditic facies, i.e. allodapic limestones, is inconsistent with the facies described above for the Prieska facles, this interpretation is evident in all papers (Beukes, 1980b; 1983; 1987: 1989; Klein et al. 1987) based on Beukes' earlier (1978; 1979; 1980a) work. But poorly developed graded bedding is described only in association with the "curly algal mats" (facies 7) in the Prieska facies. The SH-I structures of Beukes (1978) closely resemble desiccated algal mats described by Kendall and Skipwith (1969) from supratidal deposits. The abundance of fenestral structures was mentioned and a comparison to facies described by Kendall and Skipwith (1969) was made Beukes (1980a, p. 150 and Fig. 6c). Beukes (1978, p. 252) could not find any example for his interpretation of the Prieska facies in the geological literature. In our opinion this interpretation is incorrect, the confusion resulting from the rare presence of graded bedding.

The depth estimates of Klein et al. (1987) followed Beukes' (1978) interpretation. These authors described filamentous microfossils from the Gamohaan Formation in the vicinity of Danielskuil and modified the facies interpretation, which disagrees somewhat with Truswell and Eriksson (1973) and Beukes (1978). The glant stromatolite mounds are described as a part of shallow water carbonate platform occupying depths between 5 and 10 metres, and above the Conophyton type stromatolites, which are ascribed to depths of 15 to 30 metres. The break in slope between deep shelf and euxinic basin from where the filamentous microfossils were sampled was estimated to be 40 to 45 metres in depth and the maximum depth of the euxinic basin environment as 60 to 80 metres.

\section{NEW INVESTIGATIONS}

In the course of regional studies on the Transvaal Supergroup in the area between Prieska, Boegoeberg Dam and Niekerkshoop (Fig. 1), several vertical sections through the Ghaap Group carbonates were measured. These sections, together with the sedimentary facies analysis, are depicted on the following pages.

To distinguish between various carbonates in the field a solution of HCL with Alizarin red $S$ and potassium ferricyanide (Miller, 1988) was used. The solution stains calcite pink to red, ferroan calcite and dolomite blue and turquoise respectively and dolomite remains unstained.

\section{LITHOFACIES}

In the outcrops between Prieska and Westerberg, the following clastic carbonate lithofacies and stromatolite facies were observed:

1la. laminated calcareous, dolomitic and ferruginous mudstones;

lle. lenticular calcareous, dolomitic and ferruginous mudstones:

1ri. rippled calcareous and dolomitic mudstones:

2la. laminated calcareous, dolomitic and ferruginous calcarenites;

2le. lenticular calcarenites:

2cr. cross-bedded and/or graded calcarenites:

3 br. intrastratal breccias (calcirudites);

4str. stratiform stromatolites (tufted and blistered fabric);

4pol. stratiform stromatolites with polygonal cracks;

4con. Conophyton-type stromatolites;

4onc. oncolitic/pisolitic stromatolites.

The non-carbonate lithofacies in the Prieska facies are:

5 cht. Laminated cherts and ferruginous cherts (silicified facies 1-4).

6tuf. volcanic surges, lapilli tuffs and tuffs.

All the observed lithofacies are closely associated and alternate or interfinger with one another.

\section{Clastic Carbonate Faches}

Clastic carbonate facies are characterised by carbonate particles that were formed in the depositional realm and transported and redeposited within short distances. Such particles are often regarded as "in situ clastics" The particles consist predominantly of sand- and silt- to clay-sized grains of algal and pelletal origin, although in most cases it is impossible to distinguish between the two origins. Terrigenous intraclasts are very rare in 
the studied sections but the lime-mud layers can be marly and contain a significant proportion of clay minerals. The clastic carbonates are subject to widespread secondary, diagenetic dolomitization and silicification. These secondary processes often obscure the primary texture to such an extent that the original rock may have been of clastic or algal origin. Such cases are included here with the clastic facies.

\section{1la. Laminated calcareous, dolomitic and ferru- ginous mudstones (Fig. $\mathrm{GC}$ )}

Description: The laminated carbonate mudstones form centimetre to decimetre thick beds. the laminae usually being one to five millimetres thick. The lamination can be gently undulating or flat and regularly or irregularly spaced. The facies is carbonaceous and pyrite nodules and crystals are common in some beds. Ferruginous mudstones are usually better laminated than dolomite or limestone.

\section{1le. Lenticular calcareous, dolomitic and ferru- ginous mudstones}

Description: Lenticular calcareous, dolomitic and ferruginous mudstones are directly associated with facies 1 la, with which they can laterally interfinger. The lenses themselves often show distinct lamination. The lenticular bedding may have formed either by erosion (see facies 1ri.) or more likely by concretionary processes that produced "biscuits" (Mawson, 1929) and "snuff boxes" (Gatrall et al., 1972) arranged in stratiform layers (Fig. 6b) separated by laminated mudstones (facles 1la.). The "biscuits" are often Fe-rich with respect to the host laminite strata.

\section{1ri. Rippled calcareous and dolomitic mud- stones}

Description: Only erosional and wave ripples were found in this facies. The wave ripples are one to two $\mathrm{cm}$ high while the erosional (longitudinal) ripples can be up to $10 \mathrm{~cm}$ in height and $25 \mathrm{~cm}$ in wave-length. The erosional character is evident from the flat lamination of the sediment (facies 1la.), which can be followed in identical sequences from ripple to ripple, across the ripple troughs (Fig. 6a). Their crests can be slightly asymmetrical and gently curving. This facies is always interlayered with facies 1 le.

Interpretation of facies 11a - 1ri: In the outcrops discussed in the present paper the clastic origin is not always clear in the field and has been assumed because of the evidence from layers in contact with the mudstone strata. Clear evidence is, for instance, the presence of small wave ripples. On the other hand, the "biscuits" and "snuff boxes" occur in situ and only their host sediment can be regarded as clastic. Laminated carbonate mudstones are the commonest lithology. Palaeozoic to Holocene laminated carbonate mudstones are known to accumulate in supratidal to subtidal environments, but are best developed in restricted bays, ponds and lagoons of increased salinity (Wilson, 1975). However, this is based largely on the destruction of lamination in the Phanerozolc subtidalites by burrowing organisms and must be excluded for the Proterozoic. Nevertheless, the association of facies 1la., 1le. and lir. suggests an environment of tidal flats. Longitudinal ripples are most typical of intertidal flats (Van Straaten, 1951) where they form by erosion of muds through tidal current action. Their shape depends on the grain size of the sediment and the force of the current which formed them. According to Van Straaten (1951) the crests of longitudinal ripples in mud are long, parallel and straight while they become shorter and more curved with increasing grain size. In the case of carbonate mud the curved shape and the short length (one to two metres) of the longitudinal ripples can be explained by the lower adhesion forces of carbonate grains compared to clay minerals. Although algal "biscuits" are known also from subtidal environments, a typical association of intertidal flats is that of "biscuits" and longitudinal ripples. Holocene "biscuits" are typically developed in the Woakwine Range (southeastern coast of Australia) in tidal flats, flooded by some $10 \mathrm{~cm}$ of water during the wet winter season but above the water table during the summer, Mawson (1929). Whether their origin is biogenic or diagenetic is not clear. Truswell and Eriksson (1972) described biscuit-like structures associated with oncolitic facies from the Malmani Dolomite in Transvaal. The Jurassic "snuff boxes" from southern England occur together with oncolites and stromatolites in a turbulent, shallow environment under the influence of river drainage (Gatrall et al, 1972).

\section{2la. Laminated calcareous and dolomitic and ferruginous calcarenites}

Description: This facies is characterised by thin layers $(<10 \mathrm{~cm})$ of arenitic algal debris. The lamination varies on a millmetre to centimetre scale and is chiefly flat and parallel, rarely lenticular. In some layers a tuffaceous influx is recognised in the field by the slightly greenish colour caused by chlorite in the volcaniclastic sediment. These strata are interlayered with carbonate mudstone facies and partly with facies $2 \mathrm{cr}$. The lower contacts are always sharp and upper contacts mostly gradational. Strong recrystallization often obliterates primary structures. The facies consists mostly of dolarenites. 


\section{2le. lenticular calcarenites}

Description: The lenticular calcarenites occur in up to $60-70 \mathrm{~cm}$ thick layers, the lenses being one or two centimetres high and up to $10 \mathrm{~cm}$ long. Some of the lenses show internal graded lamination. The facies occurs always next to beds of crossbedded arenttes (2cr.).

\section{2cr. Cross-bedded and/or graded calcarenites}

Description: Two types of cross-stratification occur in the arenites: in the Prieska facles small current ripple cross-lamination is present. This occurs in beds up to $10 \mathrm{~cm}$ thick and is generally interlayered with mudstones and laminated arenites. Rare graded beds fine upward and simultaneously show improved sorting. Bidirectional planar cross-bedding occurs in up to $1 \mathrm{~m}$ thick beds associated with facies 21 . Directly above the Vryburg Formation up to $1 \mathrm{~m}$ thick planar or trough cross-bedded beds of carbonate and siliciclastic debris occur. Herringbone arrangement of cross-beds in these strata indicate bidirectional tidal currents. The cross-bedding set thickness attains $30 \mathrm{~cm}$. This lithology alternates with the terrigenous quartzites and fine conglomerates of the Vryburg Formation and passes upward into carbonate mudstones and stratiform stromatolites of the Nauga Formation.

Interpretation of facies 2la. to 2cr.: In the intertidal to subtidal higher energy regime carbonate sands chiefly occupy tidal bars or beaches, channels and levees. Where the planar and trough cross-bedded arenites occur, they often fill channel structures, but are also arranged in large lenticular bodies. This facies is interpreted as subtidal, marginal marine channels. The lent1cular calcarenites are interpreted as levee deposits. The laminated, ripple cross-laminated and occasionally graded arenites can be interpreted as spring tide deposits or storm deposits, (Atgner, 1985). According to Walther's Law this interpretation is more plausible than a turbidite origin for the graded beds (Beukes, 1978).

\section{3br. Intrastratal breccias (calcirudites)}

Description: The brecciated beds are usually only a few millimetres thick and seldom reach 50 $\mathrm{mm}$. They are very rare in the studied sections and are associated with laminated mudstones or algal laminites. The breccias are always of the flat pebble type, and can be clast- or matrixsupported. Imbrication was also observed. The clasts are usually uniformly sized within the same layer. Their size varies from several millimetres to 3-4 centimetres from bed to bed. In some cases where bedding surfaces are exposed, the flat polygonal breccias are in situ but exhibit some slump- ing, so that single pieces form a fitted mosalc. There is a striking association of this facies with silicification and many laminated chert sequences contain thin intrastratal breccia horizons. In some cases these intrastratal breccias accompany intrastratal disconformities.

Interpretation: The good sorting and the thin bedding of the flat pebble breccias excludes basin slope deposit origin. They are therefore intrpreted to be of shallow marine origin. In subtidal regimes incipient brecciation is common (McIllreath and James, 1980). Periodic subaerial exposure is documented by the presence of intrastratal disconformities, which are especially common in cherts. Brecciation by collapsing of beds tich in fenestrae, or collapsing after dissolution of evaportte minerals during repeated flooding of the already desiccated strata has been described by James (1980). Brecciation and formation of polygons by the force of crystallization is also known from supratidal environments (James, 1980). Brecciation by collapsing and slumping would most probably apply to the polygonal flat pebble breccias, which are often associated with stratiform algal mats with abundant fenestrae or "chicken wire" structures (see facies 4 str.). Such breccia could then be subjected to redeposition by wave action and tidal or longshore currents. A similar interpretation for the chert breccias occurring in the Eastern Transvaal was given by Eriksson et al, 1976.

\section{Stromalite Factes}

The distribution of stromatolites is controlled by various factors such as desiccation, sedimentation. cementation and erosion (Hoffman, 1976). Throughout the Phanerozoic to the Holocene the distribution of stromatolites has been controlled also by the browsing and burrowing activity of metazoan organisms (Garrett, 1970). Holocene subtidal stromatolites are rarely developed in normal marine environments (Dravis, 1983), whereas the lack of grazing metazoans in the Proterozoic allowed the stromatolites to spread into the subtidal regime below wave base (Truswell and Eriksson, 1973).

The gross morphology of stromatolites is controlled by the hydroenergy level and the direction of paleoflow (Logan et al., 1974). This control mechanism obviously remained unchanged from the Archean onward (Hofmann, 1969; Logan et al. 1974; Beukes and Lowe, 1989). In the Prieska facies only centimetre sized Conophyton structures, stratiform algal mats and oncoidal spheroids were found. As Beukes $(1978 ; 1980 a)$ observed, large columnar and domal structures are absent. 
4str. Stratiform stromatolite facies (blistered fabric)

Description: Blister algal mats were found in the Prieska facies of the Nouga Formation. The facies consist of flat to gently wavy and rarely curly micritic laminae (Fig. 5d). The algal laminations are usually about a millimetre thick and contain lenticular bodies of carbonate mud and arenite. Continuous and discontinuous laminae are common and occasionally accompanied by brecciation as well as small scale slumping (Fig. $6 \mathrm{c}$ ). Complete silicification is restricted to a few horizons, but chert lenses occur scattered throughout. Blisters can be up to $2 \mathrm{~cm}$ across and in some strata are perfectly preserved as hollow, domal shapes (especially when silicified early). However, most of the strata exhibit blisters that have collapsed or have been deformed by secondary processes and filled by calcite or quartz. Irregularly spaced, sillcified and calcified fenestrae of all shapes are most abundant, but upright and flat crystalline quartz inclusions forming a "chicken wire" pattern in the rock are also common. "Chicken wire" patterns are most abundant in stratiform stromatolites on the Orange View and Buisvlei farms.

Interpretation: Studies in the Hamelin Pool basin of Shark Bay (Australia) have shown that blistered mats are restricted to low energy intertidal and supratidal (blister) environments (Logan et al., 1974: Hoffman, 1976). Other Recent examples for stratiform stromatolites are known from Andros Island in the Bahamas (summary in Shinn, 1986) and the Trucial Coast of the Persian Gulf (Kendall and Skipwith, 1969). Precambrian analogues of these Holocene stratiform stromatolites are also interpreted as inter- to supratidal (for example: Hoffman, 1974; Eriksson et al., 1976; Beukes and Lowe, 1989). Algal mats in the Prieska facies were described by Beukes (1978; 1980a) as $\mathrm{SH}-\mathrm{I}$ structured. Evidence for supratidal and intertidal conditions in the strata described is given by the abundance of fenestral and "chicken wire" structures. The quartz crystals filling these structures have been separated from the rocks and their crystal shapes studied. Microscopically they are irregularly shaped with trapezoldal or rhomboedral imprints on the surface. They are regarded as pseudomorphs after evaporites (gypsum?). The facies of stratiform stromatolites is interlayered with carbonate lutites in sequences only a few decimetres to metres thick and forms a typical intertidal/supratidal shallowing-upward sequence (James, 1980).

\section{4pol. Stratiform stromatolite facies with poly- gonal cracks (Fig. 5a)}

Description: This subfacies of facies $4 \mathrm{str}$. consists of carbonate rocks identical to those described above, but the algal mats are desiccated into polygon structures displaying V-shaped cracks (Fig. 5a). The polygons are regularly shaped, between 5 and $10 \mathrm{~cm}$ across. The cracks are only a few millimetres deep but they developed above a vertical discontinuity in the algal laminations that forms a shallow saucer-shaped concave "bowl" when observed oblique to the bedding. The cracked stromatolites occur in stacked layers up to 20-40 cm thick. In many cases a one or two millimetre thick carbonate mud or silt "pond" has been deposited in the polygon centres.

Interpretation: The V-shaped cracks as well as the perfectly developed polygonal mosaic clearly prove that the cracks are desiccation features. To our knowledge, no synaeresis cracks are known in carbonate environments (comp. Shinn, 1986 and Smoot, 1983). Therefore we must interpret this facies as supratidal, inundated only during spring tides, storm floods or rains. Mudcracked suprat1dal stratiform stromatolites were first described by Black (1933) from Andros Island and later by Ginsburg (1955); Hardie (1977); Logan et al (1964); Hoffman (1976); Kendall and Skdpwith (1969) and many others. All of the descriptions perfectly apply to the stromatolites of the Nouga Formation. The muddy concentration in the centres of the polygons is probably the residue of the suspended sediment carried onto the supratidal flats during storm floods or by winds, and washed from the crests of the cracks into the centres of the already cemented flat bowl-shaped polygons. Hardie (1977) described 5-15 cm large polygons from Andros Island that were restricted to areas 50 to $5 \mathrm{~cm}$ above the mean tide level (the total tidal range on Andros is between 30 and $50 \mathrm{~cm}$; Shinn, 1986). These figures correspond to an exposure index of 60 to 100 (Hardie, 1977). Similar exposure indices can be assumed for the mudcrack polygons described in the present paper.

\section{4con. Conophyton-type stromatolites}

Description: The stratiform stromatolites of facles 4 str. and 4 pol. are often underlain by mats of up to $3 \mathrm{~cm}$ high Conophyton structures. The small columns are usually regularly spaced and separated by few centimetres of cryptalgal laminae. These Conophytons are up to $5 \mathrm{~mm}$ in diameter. $10 \mathrm{~cm}$ high Conophytons associated with facies 1la. and 2la. were found on the farm Nauga. They are irregularly spaced or often solitary and up to $3 \mathrm{~cm}$ in diameter.

Interpretation: Awramik (1971) described Conophyton to be the most abundant stromatolite type in the Precambrian and according to Walter (1989) Conophyton is the characteristic stromatolite of quiet subtidal environments in the Early and Middle Proterozolc. Donaldson (1976) described 
small Conophyton structures ranging into the intertidal. However, since the columns are never higher than $10 \mathrm{~cm}$, the subtidal environment must have been very shallow. The small Conophytons separated by stratiform cryptalgal laminae are interpreted as lower intertidal environment.

4onc. Oncolitic/pisolitic stromatolites (Fig. 6d)

Description: The origin of the spheroldal structures is not clear. They could be elther inorganic pisoids or algal oncoids. They may attain $10 \mathrm{~cm}$ in diameter, but are usually between 2 and $6 \mathrm{~cm}$ and of the SS-C, SS-I and SS-R types (Logan et al. 1964). SS-C types are the most common, while SSI types are very rare. The laminae of the spheroids are in the $\mathrm{mm}$ range and commonly formed upon a round or elongated, Fe-rich, haematitic (?) concretion, usually smaller than $1 \mathrm{~cm}$ in diameter. The structures are more ferruginous than the enclosing sparitic - arenitic carbonates. Closelyspaced spheroids aggregate to elongated composite structures with long axes of up to $10 \mathrm{~cm}$. The spheroidal structures occur supported by an arenitic matrix and concentrated in layers intercalated with facies 1la. and 2la.

Interpretation: Truswell and Eriksson (1973) described spheroidal structures of inorganic or organic origin, found in tabular masses, rarely associated with domal or columnar stromatolites. Their facies description implies an intertidal to agitated subtidal origin for the oncolds and/or pisoids. Oncolites usually form in shallow subtidal environments and their size increases with increasing water turbulence (Peryt, 1977; Flügel, 1982). Inversely stacked hemispheroids (SS-I) and randomly stacked hemispheroids (SS-R) of Logan etal. (1964) require periodic inversion of the spheroidal structure to allow new concentric layers to accumulate. Turbulence in the depositional realm is also evident from the arenitic matrix. Therefore the spheroidal structures grew in an environment above wave base. This environment could consist of either subtidal ponds on tidal flats or an open subtidal slope on a carbonate ramp. In the Stofbakkies section the oncoidal/pisolitic sparite is associated with mudcracked carbonate mudstone. The mudcracks are V-shaped and form large polygons up to $20 \mathrm{~cm}$ across. They are entirely filled with whitish chert, whereas the polygon interior is also filled with round chert patches (Fig. 5b). These polygons are regarded as desiccation cracks. Such a syngenetic chert within desiccation polygons was described by Harris (1958). Apparently the tidal ponds were subject to some desiccation or the subtidal flat was shallow enough to be exposed during extremely low tides. bcht. Laminated cherts and ferruginows cherts

This facies is a subfacies of facies 1 and 4. The cherty silicification is secondary and the primary carbonate facies was described above.

\section{6tuf. Tuffe and tuffites}

This facies consists of bedded, cross-bedded, and graded tephra with accretionary lapilli (phreato-volcanic surges and ash falls). The volcanic rocks of the Nouga Formation will be the subject of another paper.

\section{FACIES RELATIONSHIP IN REGIONAL CONTEXT}

The arrangement of lithofacies sequences can be deduced from the sections in figures 2 and 3 . From these sections it is evident that the different facies comprise a shallowing-upward cycle from subtidal to supratidal environment.

For comparison with more complete shallowingupward sequences from the Campbell Group, a section through the upper Kogelbeen Formation and the Gamohaan Formation was recorded at Kuruman Kop near Kuruman (Fig. 4). Here domal, columnar and cauliflower stromatolites representing subtidal environments, are exposed. The shallowing-upward cycles generally start with domal stromatolites, which consist of curly laminated mats (LLH-S/LLH-C). The domal structures In the studied section do not exceed $50 \mathrm{~cm}$ in height but larger domes exist lower in the stratigraphic section. The domes are closely spaced, but etther separated or laterally linked near the base (SH-C $\longrightarrow>$ LL-S $\rightarrow>$ LL-C). The space between the domes is generally filled with pelsparitic grainstone. Where the cycles are more complete the domes pass upward into columnar stromatolites of generally unbranched cylindrical and rarely bifurcating cylindrical columns (SH-V $\longrightarrow>L L H-$ $\mathrm{C} \longrightarrow>\mathrm{SH}-\mathrm{V}$ ). The stromatolite columns are occasionally linked by thin laminae, but the intercolumnar space is usually filled with pelsparitic grainstones (SH-V $\longrightarrow>\mathrm{SH}-\mathrm{V}$; Columno-collenia and Kusiella lined by Collenia structure). The columns are up to a few decimetres high. These columnar stromatolites most probably represent a higher energy subtidal environment. Above the columnar structures thin horzons of Conophyton columns up to $10 \mathrm{~cm}$ high may be developed. The columns are regularly spaced, inclined and linked by thin laminae separated by large blisters filled with coarse, sparry calcite. The uppermost few centimetres of these structures are subject to small scale slumps and they are usually covered by a thin veneer of dark carbonate mud. The Conophyton mats are completely barren of clastic carbonate. They probably indicate an upper subtidal environ- 


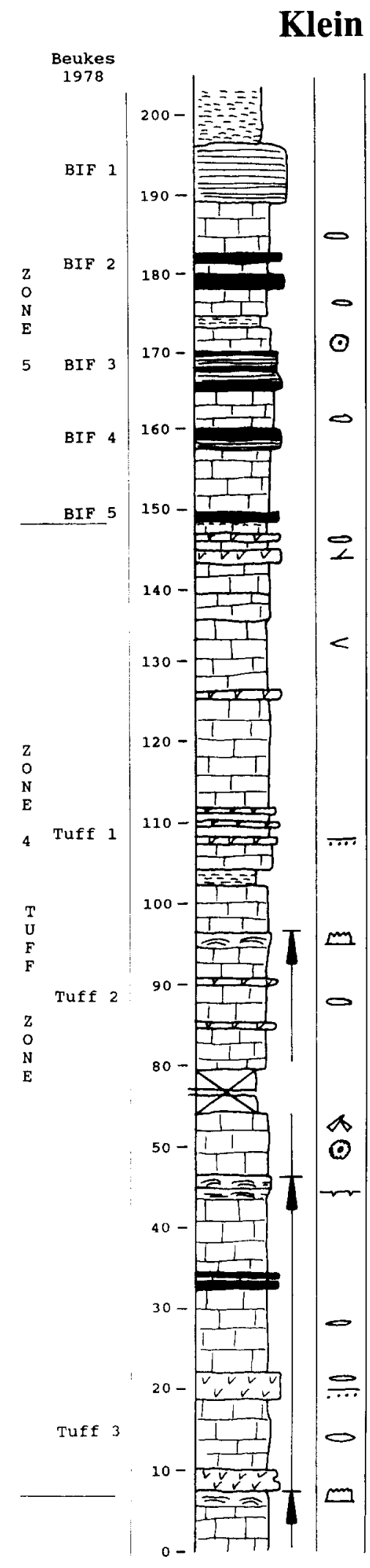

\section{Orange View / Buisvlei}

NAUTE SHALES

Proto-BIF: Fe- rich cherts and carbonates, finely laminated and thin-bedded

Proto-BIF: Fe- rich cherts and carbonates, finely

lamlnated and thin-bedded

oncoidal and pisolitic

sparites (SS-I and SS-R)

Proto-BIF: Fe- rich cherts and carbonates, finely

laminated and thin-bedded

Proto-BIF: Fe-rich cherts and carbonates

Tuff intercalations cross-bedded, lenticular

Clastic laminated lutitic and sparitic dolomites and limestones, Fe-rich

Tuff intercalations

Carbonate lutites and arenites

Tuff intercalations, graded

Marly - shaly

stratiform stromatolite facies:

agal and cryptalgal laminites and bindstones, finely bedded clastic laminites, abundant fenestral fabrics, recrystallized stromatactis
common lenticular bedding

25m NO OUTCROP

oncoidal and pisolitic sparites (SS-I and SS-R)

Stratiform stromatolite facies, with desiccation cracks, abundant fenestrae

Chert intercalations

Clastic, laminated, lutitic and sparitic dolomites and 1 imestones, Fe-rich

Tuff intercalations, graded

Tuff intercalations

stratiform mats, thin platy carbonate lutites and arenites, rippled and laminated, lenticular

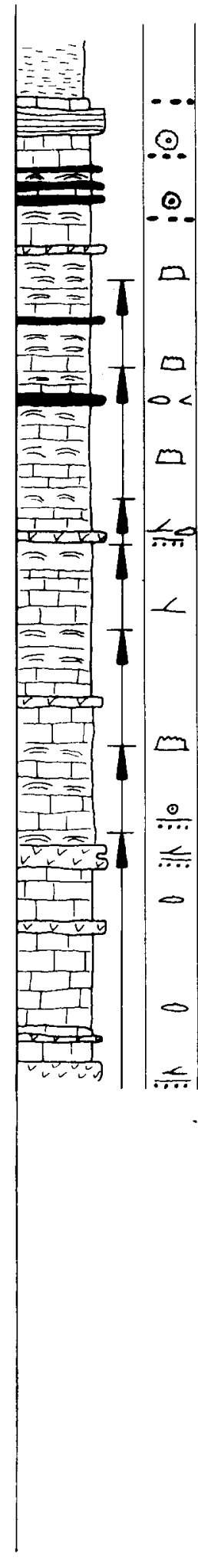

NAUTE SHALES

Proto-BIF: Fe- rich cherts and carbonates, finely laminated and thin-bedded

oncoidal and pisolitic micrites and sparites (SS-I and SS-R) Fe-rich concretions

Tuff intercalations

Fe-rich chert intercalations with thin intrastratal, flat pebble breccias

Tufe intercalations, graded, cross-bedded and laminated

stratiform stromatolite facies :

agal and cryptalgal

laminites and bindstones

finely bedded clastic

laminites, abundan

fenestral fabrics

recrystallized stromatactis abundant lenticular and wavy beds

Tuff intercalations, graded, cross-bedded and laminated

Carbonate lutites and arenites, stratiform algal mats

Tuff intercalations, graded, cross-bedded, laminated and lenticular

Fig. 2. Measured sections through the uppermost Nouga Formation,in Klein Naute $(200 \mathrm{~m})$ and Orange View $(150 \mathrm{~m})$ region, with correlation to the zones of Beukes (1978). Arrows mark large scale shallowing upward sequences. 


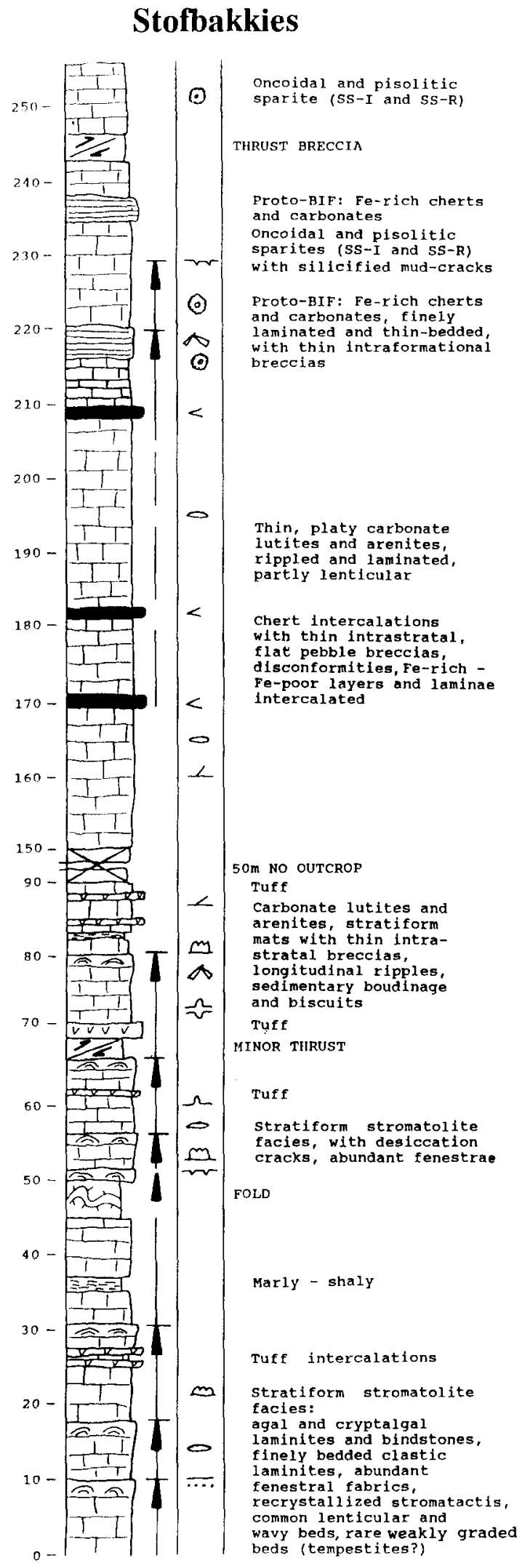

Fig. 3. Measured section through the uppermost Nouga Formation, in Stofbakkdes area $(250 \mathrm{~m})$. Due to outcrop conditions the soction is composed from several overlapping sections. Arrows mark large scale shallowing upward sequences.

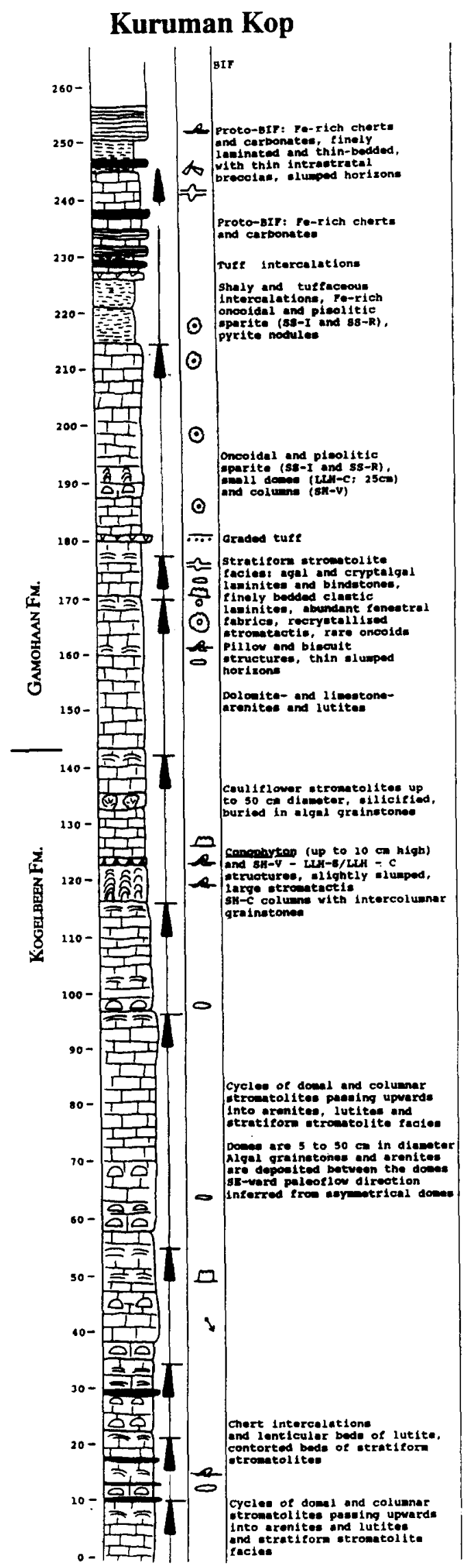

Fg. 4. Measured section through the uppermost Kogelbeen (Ghaap Plateau facies) and the Gamohaan Formations at Kuruman Kop (260 m). The shallowing-upward cycles (arrows) start with domal stromatolites (subtidal) and end with strattform stromatolites (upper intertidal to supratidal). 

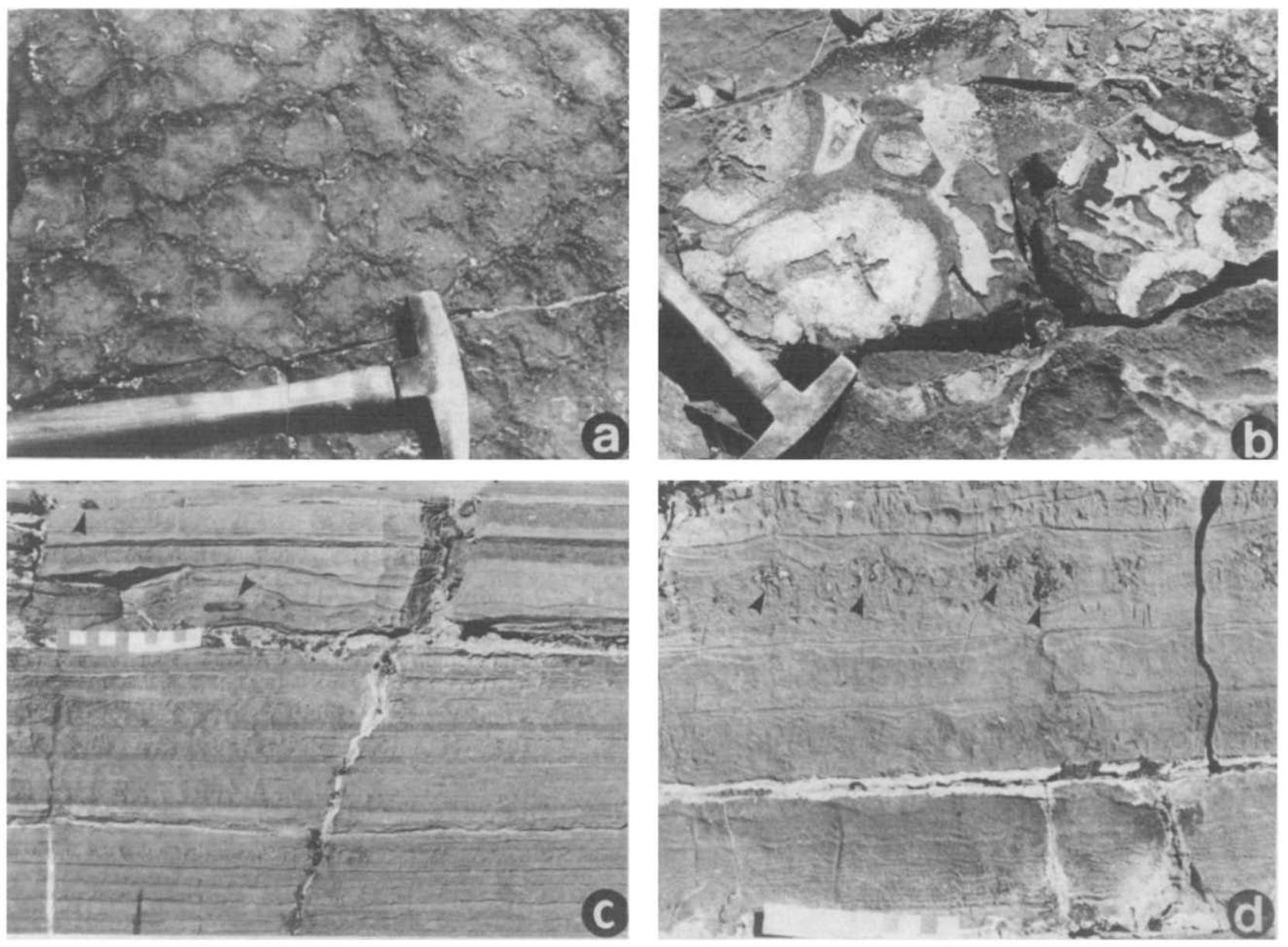

Fig. 5. Lithofactes of the Prieska facies carbonates. Scale bars equivalent $10 \mathrm{~cm}$.

a. Dessiccation cracks in the stratiform stromatolite facies (facies 4 pol.). The cracks are partly filled by white calcite and are V-shaped. The polygons display flat saucer-shapes evidencing early cementation.

b. Silicified desiccation polygons from the oncolitic/pisolitic facies. The cracks are V-shaped and filled with gray chert whereas the polygons are filled with white chert.

c. Laminated dolarenites and lutites. Intercalation of facies 1la. and 2la. Notice the presence of chert lenses (arrows).

d. Stratiform stromatolite facies (4str.) with recrystallised, partly quartz-filled fenestrae (arrows).

Note the U-shaped nature of the uppermost part of each stromatolitic cycle. In a three-dimensional exposure these structures appear as polygons and are probably ill-developed desiccation structures.

ment. Clastic carbonates and strattform mats represent intertidal environments higher in the section, but upper intertidal facies and desiccated mats were not found near Kuruman.

More complete descriptions of lithofacies in the Ghaap facies are given by Young (1935), Truswell and Eriksson (1973). Beukes (1978; 1980a) and Klein et al (1987). Similar shallowing-upward cycles consisting of giant domal stromatolites at the bottom, which pass up into columnar structures, and finally into intertidal sands and inversely (growth) graded oolites were recently described from the eastern Transvaal (Clendenin, 1989).

\section{MCROFACIES}

Microfacies studies of the carbonate sediments were based on $5 \times 5 \mathrm{~cm}$ and $2.5 \times 5 \mathrm{~cm}$ petrographic thin-sections of over 60 samples from the Prieska facies, selected according to macroscopic facies observations in the field. The samples are from the Prleska, Klein Naute - Orange View and the Geelbeksdam regions.

Three megafacies types were discerned, that could be differentiated into several microfacies types:

I. ALLOCHEWTCAL CARBOKATE BEDNuENTE

I.A Intraclastic pack-/rudstones

I.B Oncolitic pack-/rudstones

\section{Cryptalan Bindotones}

II.A Stromatolitic cryptalgal bindstones

II.B Laminated cryptalgal bindstones

II.C Laminoid cryptalgal bindstones

\section{LAMINITEB}

III.A Laminites with delicate parallel lamination III. B Laminites with undulating parallel strattff- 

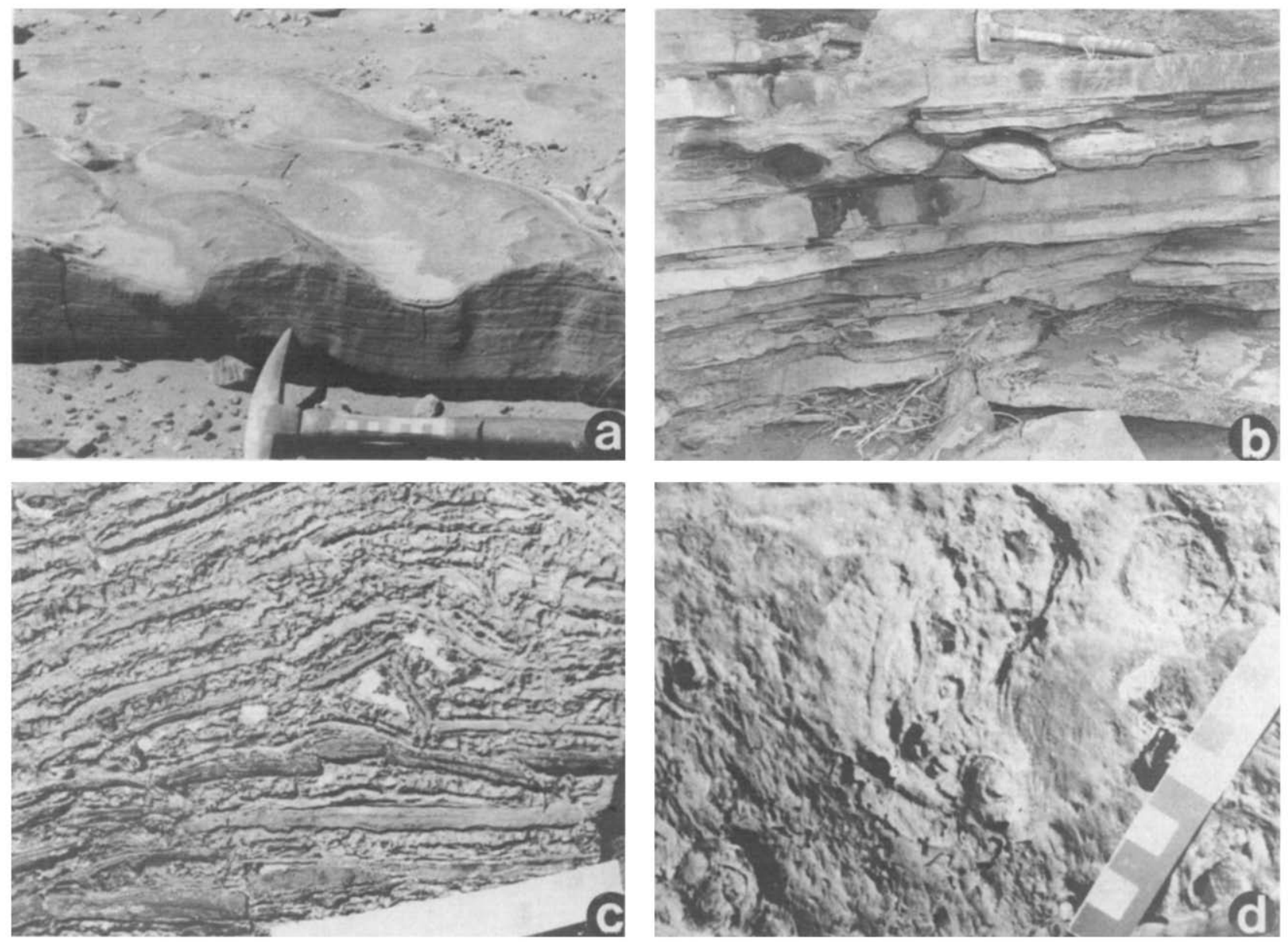

Fyg. 6. Lithofacies of the Prieska facles carbonates. Scale bars equivalent $10 \mathrm{~cm}$.

a. Longitudinal, erostve ripples in a laminated carbonate mudstone (facies $1 \mathrm{r}$.).

b. Biscuit structures in a carbonate mud layer.

c. Slumped and slightly brecciated intercalation of clastic facies (1la.) and stratiform stromatolite facies (4str.). Note the sparry calcite fillings of the cavities originated within the slump structure. They indicate that the slumped beds were already partly cemented and therefore did not collapse.

d. Oncolitic facies (4onc.). Ferruginous oncolites embedded in dolarenite. The large structure in the middle of the photograph is composed of three smaller oncolites.

\section{cation}

\section{III.C Ferruginous ("ankeritic") laminites}

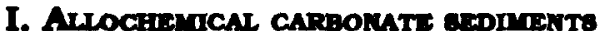

Allochemical carbonate sediments are characterised by the predominance of intraclasts formed within the depositional realm and have suffered some transport (Folk, 1959). They are very rare in the studied material. The carbonates may be epigenetically silictfled or overprinted by stylolites. forming stylo-breccias.

\section{I.A Intraclastic pack/rudatones (Figs 7a, b)}

Description: These are clast-supported flatpebble conglomerates, mostly subangular, but also well-rounded, often imbricated or cross-bedded lithoclasts in a micrite to sparry calcite matrix. The lithoclasts are derived from the reworking of microfacies type III.A (laminites with delicate parallel lamination). They are $4-8 \mathrm{~mm}$ thick and $8-15 \mathrm{~mm}$ long. In a sample from Klein Naute most of the lithoclasts show thin ferruginous envelopes (Fig. 7b) that penetrate unevenly into the grains. They are therefore classifled as cortoids (Flügel, 1982).

Interpretation: Agitated shallow water environments are indicated by the reworking of laminites of probable cryptalgal origin (see microfacies III. A), as well as by the well-winnowed sparry calcite matrix. Moreover, the cortold formation is attributed to endolithic micro-organisms (e.g. bacteria. cyanobacteria), which are expected to flourish in warm shallow water environments; the formation of cortoids also depends on at least episodic turnover of the grains. Flat-pebble conglomerates with micritic matrices probably were transported into deeper-water realms below wave base.

\section{I.B Oncolitic pack-/rudstones}

Description: Oncolds with diameters of 5-50 

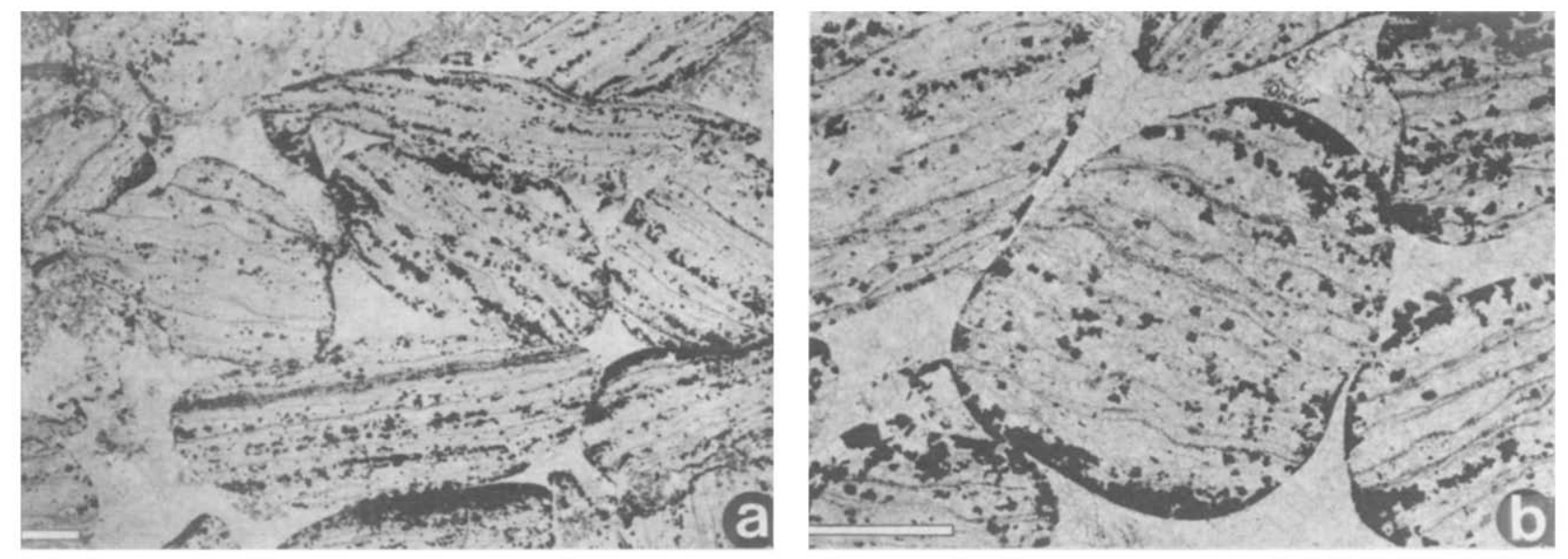

Fig. 7. Microfacies of allochemical carbonate sediments. Scale bars equivalent $2 \mathrm{~mm}$.

a, b. Microfacies I. A - Intraclastic pack-/rudstones. Sample WA88/183. A: imbricated

lithoclasts dertving from the reworking of microfacies-type II. A (laminites with delicate parallel lamination). B: A cortoid with a ferruginous envelope.

$\mathrm{mm}$ are embedded in a coarse-grained, blocky sparitic matrix. The ferruginous, micritic oncoids are well-defined concentric layers. SS-C, SS-I, SS$\mathrm{R}$, and composite types are common. Spar intaclasts are often developed as cortoids.

Interpretation: The formation of SS-R and SS-I oncoids requires perlodic overturning of spheroldal structures. The sparry calcite matrix suggests a rather turbulent environment, where sporadic currents and waves were active. These forces were probably triggered by storms in a subtidal environment, above wave base or lagoons of low sedimentation rates (Flügel, 1982).

\section{Cryptalanl bindetones}

Cryptalgal bindstones originate from the sediment-binding and/or mineral-precipitating activities of non-skeletal algae (mainly cyanophyceans/ cyanobacteria) and bacteria (Aitken, 1967; Monty, 1976). These bindstones are characterised by dense algal laminations exhibiting an irregular anastomosing fabric. Well-defined, laterally persistent sedimentary layers of differing consistency and fabric, like those in laminites, are missing. Using the standard microfacies types (SMF-types) introduced by Flügel (1972; 1982) and Wilson (1975), cryptalgal bindstones would correspond to SMFtypes 20 (algal stromatolite mudstone) and 21 (spongiostrome mudstone), whereas laminites would have to be grouped with SMF-type 19 (laminated pelleted mudstone/wackestone, loferite).

\section{II.A Stromatoolitic cryptalgal bindstones (Figs 9b, c) \\ Description: Stromatolitic domes in samples from Orange View are clearly of Conophyton type.}

built up of fine, very regular laminae of peloids and associated micritic filaments, both supposedly of cryptalgal origin. The characteristically conical peloid/fllament laminae are grouped together in layers a few $\mathrm{mm}$ thick. They are differentiated from one another by the degree of packing, thus forming alternately spar-dominated and component-dominated layers. Large, spar-filled fenestrae situated close to the axis of Conophyton (Fig. 9c) were tentatively attributed to the entrapment of gasbubbles (Donaldson, 1976). The Conophytons form approximately $5 \mathrm{~cm}$ high, $3-4 \mathrm{~cm}$ wide, isolated domal structures with pronounced vergence. They developed from a less updomed, more irregular, partly oncolitic base.

Interpretation: Middle and Upper Proterozoic Canadian Conophytons were interpreted to range from subtidal environments below wave-base to intertidal environments (Donaldson, 1976). Shallow subtidal to intertidal specimens were described as small, discrete, distinctly inclined columns. $3-10 \mathrm{~cm}$ in diameter. These strongly resemble the Orange View specimens. In the case of the Orange View Conophytons, shallow agitated water is also suggested by the oncolitic base of the cryptalgal structures.

\section{B Laminated cryptalgal bindstones (Figs 8a, b; 9a) \\ Description: These bindstones show a typically} irregular, wavy to wrinkled, laminated fabric consisting of alternately micrite-dominated and spardominated layers, each some millimetres thick (Fig. 8a). The micrite-dominated layers may form microdomes and incipient nodular structures. They partially preserve irregularly distributed agglutinated cryptalgal peloids (Fig. 8b). Trapping of tiny sparitic intraclasts and small detrital quartz grains is common in samples derived from the Vryburg 

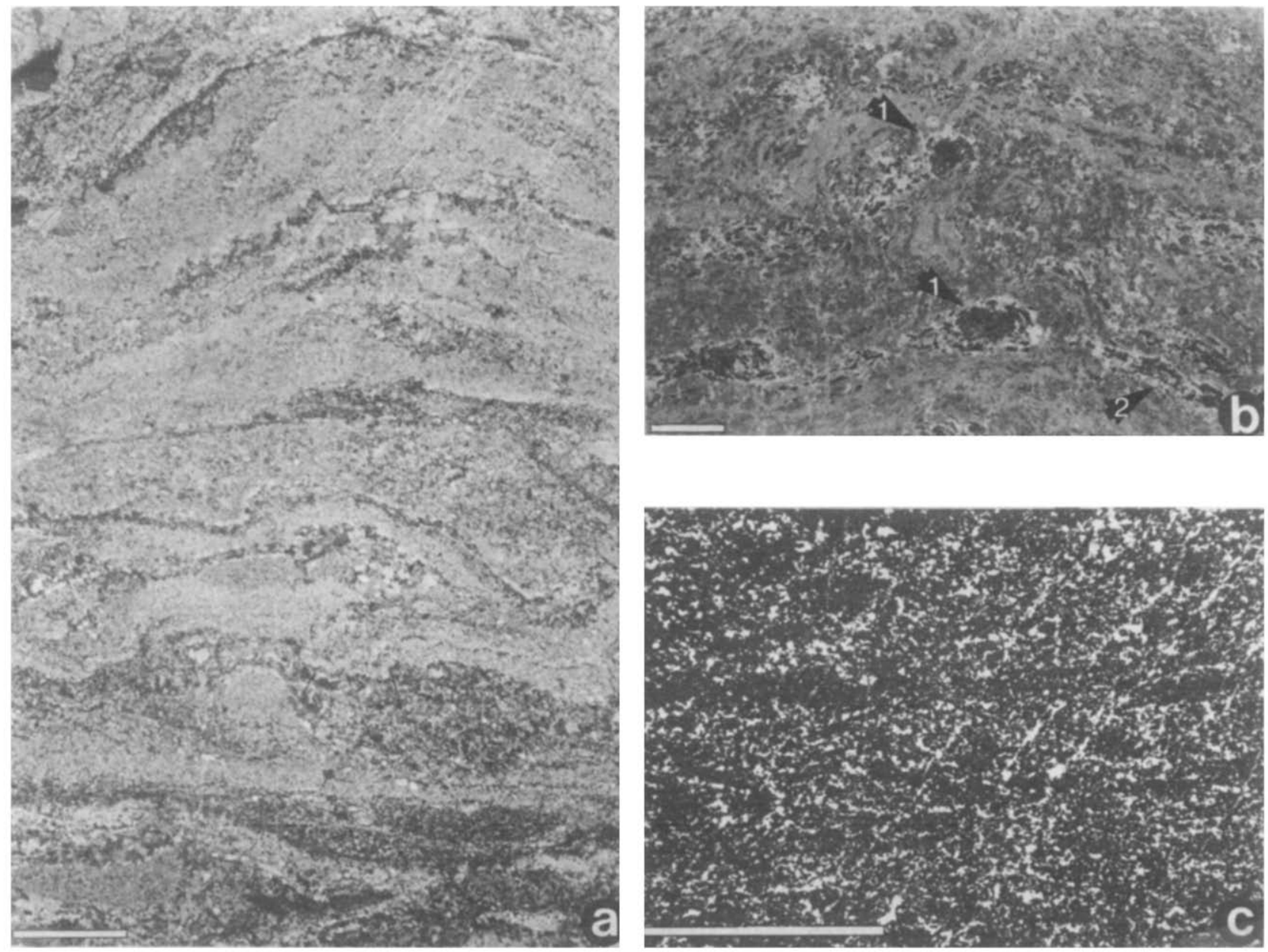

Fig. 8. Microfacies of cryptalgal bindstones and ferruginous (*ankeriticn) laminites. Scale bars equivalent 2 mm. a,b. Microfacies II. B - Laminated cryptalgal bindstones. a: Typical anastomosing bindstone texture: Sample WA88/ 35. b: Interwoven bindstone laminae with cryptalgal peloids and fenestrae (arrows 1: birdseyes, arrow 2: laminoid); Sample WA88/298a.

c. Microfacies III. C - Ferruginous (aankeritic) laminites. Densely packed, horizontally layered, clotted peloids and fine fenestral texture; sample WAB8/388.

Formation transitional beds to the Campbell carbonates (Fig. 9a). Fenestral fabrics (laminoid fenestrae, birdseyes) are represented by cavities filled with blocky spar (Fig. 8b). Geopetal fabrics are formed by infill of sediment which is topped by blocky sparite in a few stromatactis-type fenestrae with relatively flat bases and irregular roofs (Fig. 9a).

The sediment consists of dolomite or ferruginous dolomite. Some of the spar-dominated layers are epigenetically silicified.

Interpretation: In Phanerozolc times, cryptalgal bindstones and associated fenestral fabrics occurred preferentially in protected intertidal to marginal supratidal environments. They are wellstudied in contemporary sedimentary settings. The microfacies type here described is tentatively linked to the morphologically diversified and widespread smooth cryptalgal mats, that are confined mainly to the lower intertidal zone in con- temporary sediments from Shark Bay, Western Australia Logan et al. (1974). Eriksson and Truswell (1974) and Eriksson (1977) noted remarkably similar facies types in the Lower Proterozoic carbonate sediments of South Africa and suggested a deposition in analogous sedimentary environments.

\section{II.C Laminoid cryptalgal bindstones (Fig. Od)}

Deecription: No distinct lamination as in the microfacies type II. B (laminated cryptalgal bindstones) is seen in the strongly ferruginous sediment. Large, Irregular, spar-filled fenestrae. arranged more or less horizontally, are abundant. Ferruginous cryptalgal (?) lumps are common.

Interpretation: This microfacies type is comparable to blister algal mats (Logan et al. 1974) which are known from Holocene upper intertidal flats supratidal zones and also occur in the Lower Proterozoic of Transvaal, South Africa (Eriksson and Truswell, 1974). 

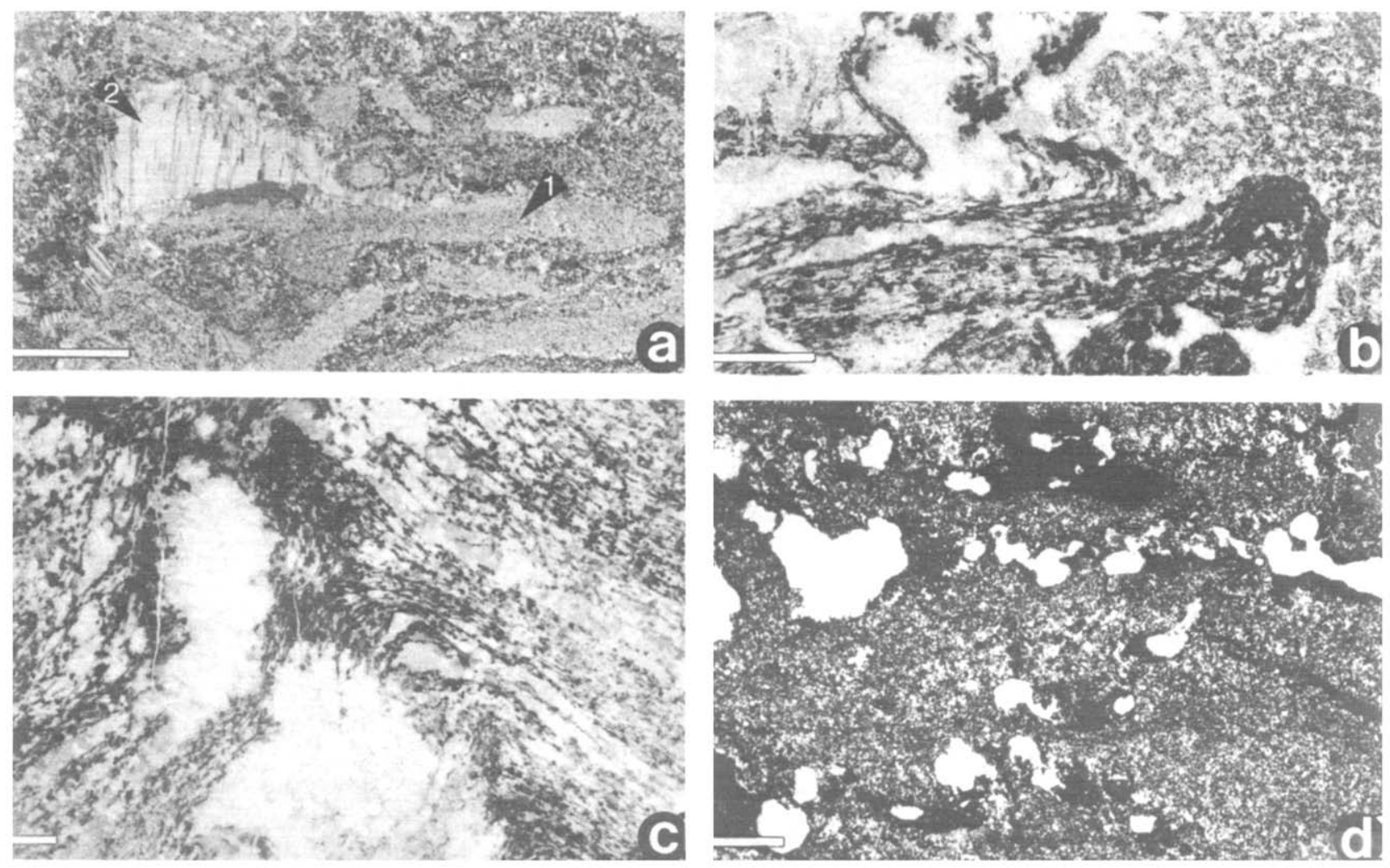

Fyg. 9. Microfacies of cryptalgal bindstones and ferruginous ("ankeritic") laminites. Scale bars equivalent 2 mm. a. Microfacies II. B - Laminated cryptalgal bindstones. Stromatactis-type fenestra with even base and irregular roof. Note basal (silicified) Internal sediment (1) which is topped by sparite (2). Trapping of fine detrital spar and quartz grains is common; Sample WA88/35.

b, c. Microfacles II. A - Stromatolitic cryptalgal bindstones. b: Irregular, in part oncolitic base of Conophyton; sample WA88/332b. c: Vergent Conophyton with large spar-filled fenestrae which might be due to the entrapment of gas bubbles; sample WA88/332a.

d. Microfacies II. C-Laminold cryptalgal bindstone. Large, Irregular fenestrae and lumps in a strongly ferruginous sediment without distinct lamination; sample WA88/294.

\section{InAmIm:}

Laminites are the most common facies type encountered. Although an essential contribution of cryptalgal structures to sediment formation can be proved in many cases, a differentiation into single, well-defined and latrally persistent, often microlayered laminae of different consistency, fabric, and thickness is obvious. Thus, laminites are clearly distinguished from the more irregular and interwoven habit of cryptalgal bindstone laminae. The laminite facies corresponds approximately to standard facies type 19 (laminated pelleted mudstone/wackestone) of Flügel (1972; 1982) and Wilson (1975).

In general the laminites document quiet, mostly undisturbed sedimentation. Only a few samples. all belonging to microfacies type IIIa (laminites with delicate parallel lamination), record smallscale sedimentary disturbance and transport. This includes slumping of horizons maximally 2 cm in thickness (Fig. 11d) and channeling of up to $1 \mathrm{~cm}$ thick horkons. Sedimentary breaks are documented by Fe-impregnated hardgrounds associated with relief-forming solution/erosion of underlying laminae and overgrowth by millimetresized, low domal ferruginous stromatolites respecttvely (Fig. 10c), and by desiccation cracks (Fig. 10d).

\section{III.A. Laminites with delicate parallel lamination (FIgs 10c, d; 11a, c. d)}

Description: This microfacies type is characterised by strongly parallel, millimetre-sized, alternate feruginous carbonate laminae and spardominated laminae which may be epigenetically silicified. The thickness of the individual laminae is subject to minor modifications. In gneral, ferruginous layers, often "one-grain-laminae", are thinner than spar-dominated layers (Fig. 11 a). Although essentially planar and parallel, slightly crinkled or wavy ferruginous laminae predominate. Therefore the ferruginous laminae are interpreted to represent mineralised cryptalgal structures. This is clear not only by virtue of their dominantly crinkled structure, but also by the 

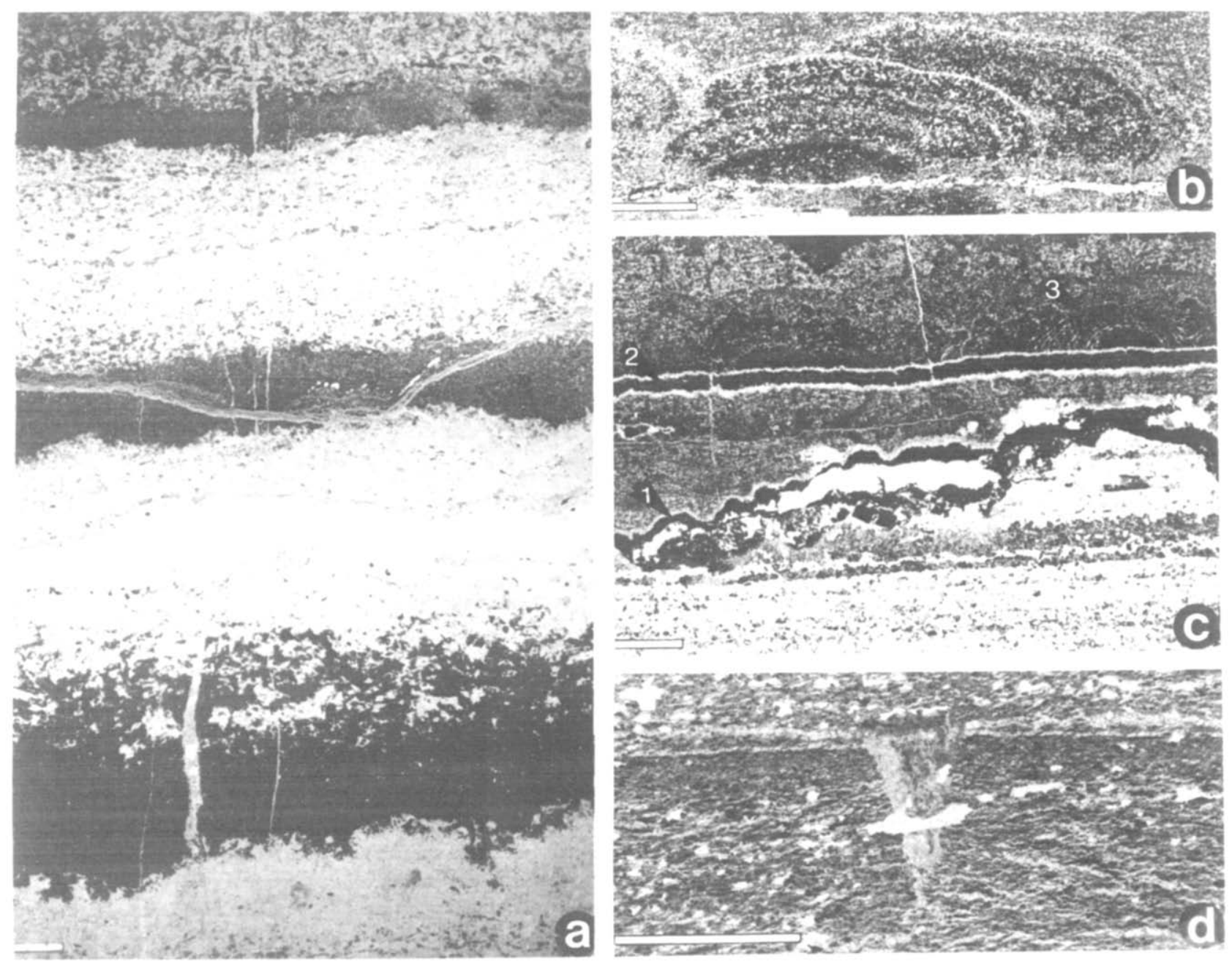

Fig. 10. Microfacies of laminites. Scale bars equitvalent $2 \mathrm{~mm}$.

a. Microfacies III. B - Laminites with undulating parallel layering. Dark: ankeritic layers, light: spar-dominated layers, white: epigenetic silicification. Low-domal structures at the top of the lowermost spar-dominated layer point to loss of cryptalgal structures. Note also mushy network with fenestral fabrics on top of lowermost ankeritic layer; sample WA88/363.

b, c. Microfacies IIl. C - Ferruginous ("ankeritic") laminites. b: Low domal, cushion-like micro-stromatolites composed of clotted cryptalgal peloids; sample WA88/304. c: Intimate association with microfacies III. A (laminites with delicate parallel layering) below hardground 1. Sedimentary breaks are documented by highly ferruginous hardgrounds. Hardground 1 developed on top of a solution/erosional surface; hardground 2 is overgrown by ferruginous micro-stromatolites (arrow 3); sample WA88/206a.

d. Microfacies IIIa - Laminites with delicate parallel lamination. Desiccation crack extending into flasered carbonate mud; sample WA88/172.

exdstence of clothed cryptalgal pelolds in both spar-dominated and ferruginous laminae (Fig. 11c). as well as the presence of ferruginous, low domal, cushion-like micro-stromatolites in the associated microfacles type III.C (Ferruginous laminites; compare Figs $10 \mathrm{~b}, \mathrm{c})$.

In several plurely dolomitic or epigenetically to late diagenetically silicified samples only faint differences in colour and/or crystallite size were observed; cryptalgal structures may be obliterated or completely lacking.

Figure lod shows a unique feature among the studied material. It consists of markedly parallel approximately $10 \mathrm{~mm}$ thick layers of carbonate mud with abundant bedding-plane parallel, tiny sparitic flasers. The flasered mud-layers are separated by $0,25-0.5 \mathrm{~mm}$ thick sparitic laminae bullt up of crystallites oriented mostly vertically to the beding-plane. A few sparitic wedges extend from these laminae into the underlying muddy layers. They are interpreted as desiccation cracks.

This microfacies type is commonly associated with type III.C (ferruginous laminites).

\section{III.B Laminites with undulating parallel stratification (Figs 10a, 11b)}

Description: These laminites are characterised by parallel, dwavy, several millimetres to more 

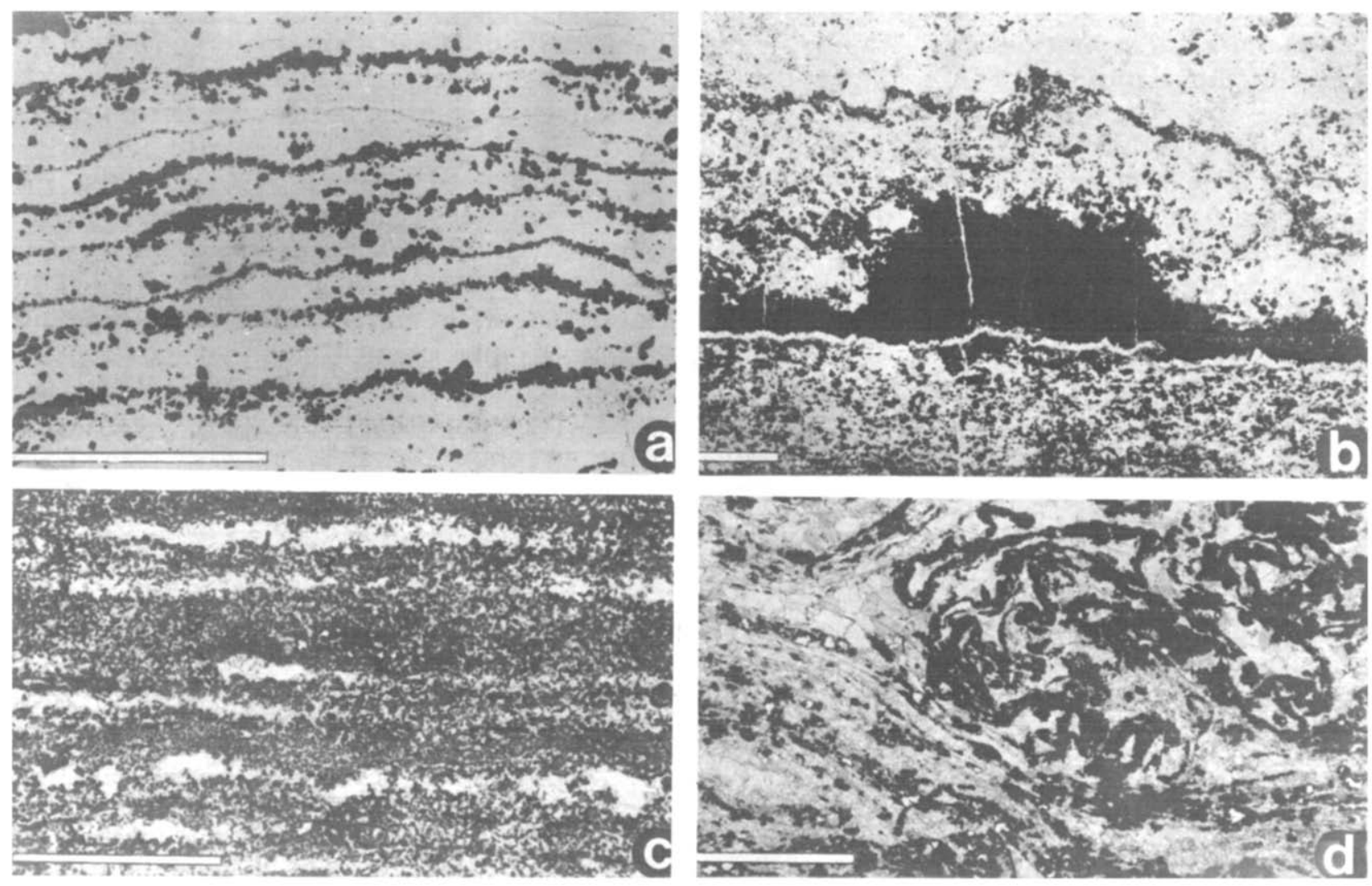

Fig. 11. Microfacies of laminites. Scale bars equivalent $2 \mathrm{~mm}$.

a. c. d. Microfacies Illa - Laminites with delicate parallel lamination. a: Wavy parallel lamination.

Note ankeritic "one-grain-laminae"; sample WA88/177. c: Mostly agglutinated peloids and

laminoid fenestrae in a predominantly ferruginous specimen; sample WA88/341.

d: Contorted cryptalgal laminae in a slumped horizon; sample WA88/388.

b. Microfacies III. B - Laminites with undulating parallel layering. Domal cryptalgal structure on top of an ankeritic layer, mimicked by the overlying spar-dominated and ankeritic layers. This points to unpreserved, but essential cryptalgal activity also in the spar-dominated layer and to its rapld cementation; sample WA88/340.

than one centimetre thick layers. As in microfacies II. A (laminites with delicate parallel lamination). some purely dolomitic samples are throughly recrystallised and record only faint relics of wavy internal bedding. Samples with alternate spardominated and ferruginous ("ankeritic") layers clearly exhibit primary sedimentary structures and textures. Spar-dominated layers contain single peloids, clotted peloids and small lumps, all are markedly ferruginous and identical to the components predominating in the ankeritic layers. The components within the spar-dominated layers are arranged more or less horlzontally, commonly in a crinkled or slightly updomed manner. They form dotted "one-grain" laminae to mushy multi-grain laminae. Ankeritic layers often comprise horizontally layered, densely packed tiny peloids. The boundaries between the laminae show gradation in ferruginous components. Thus, they can form a mushy network with laminar fenestrae and/or birdseyes at the base and/or top of the dense ankeritic layers (Fig. 10a). Low domal structures are present at the top of some ankeritic and spardominated layers (Fig. $11 \mathrm{~b}$ and 10a). In this way. they demonstrate the former existence of unpreserved (1.e. not mineralised) cryptalgal structures also within the spar-dominated layers, as well as rapid cementation.

\section{III.C Ferruginous ("ankeritic") laminites (Figs 8c, 10b, c)}

Description: This microfacies type forms ankeritic layers several centimetres thick many of which are closely associated with microfacies III.A (lamlnites with delicate parallel lamination; compare Fig. 10c). In fact, some samples represent III.A laminites with minor spar-dominated laminae. Other samples, however, are characterised by horlzontally laminated, densely packed, clotted peloids and very delicate fenestral structures (Fig. 8c), thus resembling the ankeritic layers of microfacies type III.B (laminites with undulating parallel layering). Tiny, (up to $5 \mathrm{~mm}$ high) domal, stromatolites also occur (FIgs. 10b, c). Quite homogeneous ankeritic masses with only faint traces of lamination are thought to be the result of diagenetic overprint.

Interpretation: Since a cryptalgal origin for 
most of the samples is evident, a protected intertidal to marginal supratidal deposition is postulated for the laminites. The samples closely resemble the contemporary "smooth algal or cryptalgal mats" that flourish mainly in the lower intertidal zone of protected embayments of Shark Bay, Western Australia (Davies, 1970; Logan et al. 1974). Eriksson and Truswell (1974) and Erksson (1977) described analogous laminites in the Lower Proterozolc carbonates of South Africa.

\section{THE DEPOSITIONAL REALM}

In the Prieska facies, cryptalgal sediments (different types of bindstones and laminites) predominate. Rare allochemical carbonate sediments are either reworked cryptalgal sediments or represent brief intermittent higher energy episodes in a shallow subtidal environment where oncoids were formed by cyanobacterial and algal activity.

Contemporary environments where algal mats form. namely Shark Bay and the Persian Gulf, are obvious models of the Proterozolc depositional environment (Eriksson and Truswell, 1974; Eriksson, 1977). Deposition of the Campbell carbonate sediments along the Orange Rtver between Prieska and Westerberg probably took place predominantly in a protected intertidal to supratidal realm. The different cryptalgal facies types suggest that the shoreline was unstable.

The most restricted facies is represented by microfacies type II.C (laminoid cryptalgal bindstones), which is corelated with present day blister algal mats from upper intertidal and supratidal zones. The remaining cryptalgal bindstones and laminites are different morphological, i.e. environmental and/or bjological expressions of the contemporary smooth algal mats described from Shark Bay. Although they are confined mainly to the lower intertidal zone, they also extend into the middle intertidal zone.

A paleoenvironmental differentiation of the corresponding facles types is difficult, but could be achieved by relying on the different thicknesses and morphological expression of the the cryptalgal laminae. Logan et al. (1974, p. 152) and Monty (1976) showed the complex modes of origin of layered cryptalgal fabrics. However, the growth of different laminae is governed mostly by periodic or episodic changes, whereas a single lamina is considered to represent a continuous growth process. Growth interruption seems more probable in more restricted higher intertidal zones or in tidal ponds. Therefore, thicker cryptalgal laminae with less regular surfaces are expected to predominate in the latter environments. According to this model, microfacies type III.A (laminites with delicate parallel lamination) should reflect very thin films of restricted algal growth, probably on often emergent tidal flats. Desiccation cracks and hardgrounds displaying typical features such as relief formed by erosion or dissolution of the underlying sediment, or overgrowth by ferruginous stromatolites, are almost restricted to this type.

Eriksson and Truswell (1974) considered flat (smooth) laminites from the South African Proterozoic to be mostly of upper intertidal to supratidal origin and mentioned the possibility of evaporite replacement. The microfacies types II. B (laminated cryptalgal bindstones) and III. B (laminites with undulating parallel layering), recording a more pronounced algal growth of thicker algal laminae with slightly undulating surfaces, occur in a less restricted. lower intertidal environment or in tidal ponds. Stromatolitic cryptalgal bindstones of the Conophyton-type described (microfacies II. A) are still of intertidal origin. The distinct inclination of the small domes and their oncolitic bases indicate slightly agitated environments in a lower subtidal realm.

The low energy environment is exemplified by the almost complete lack of reworking, which is restricted to some flat-pebble conglomerates. Additionally, tidal creeks and other morphologic features subdividing the environment are very rare. The main sedimentary environment is therefore interpreted as a protected tidal flat extending into the supratidal zone, adjacent to a deeply eroded terrestrial lowland.

\section{REGIONAL CONTEXT}

Eriksson and Truswell (1974) regarded carbonate sediments with flat (smooth) laminites from the northern Cape, south of Vryburg, similar to those described in the present paper, as upper intertidal to supratidal deposits. Beukes and Lowe (1989) interpreted stratiform stromatolites from the Archean Pongola Group to be intertidal. Beukes (1978; 1980a) interpreted the Prieska facies as turbiditic or endoclastic basinal facies. The facies described in this paper suggest that Beukes (1978; 1980a) interpretation cannot be upheld as the rocks are exclusively shallow subtidal or supratidal deposits. The recorded facies and microfacies in the Campbell carbonates clearly prove the existence of tidal flats along the present southwestern margin of the Kaapvaal Craton.

Most of the studied material is highly ferruginous. The Campbell Dolomite in the vicinity of Prieska was thus described by Eriksson et al. (1976). Button (1976) showed iron formations in the eastern Transvaal to be an end member in a succession of carbonate cycles; iron precipitation took place in a barred basin or lagoon, 1.e. in the most marginal zone of the basin. Beukes (1978) 


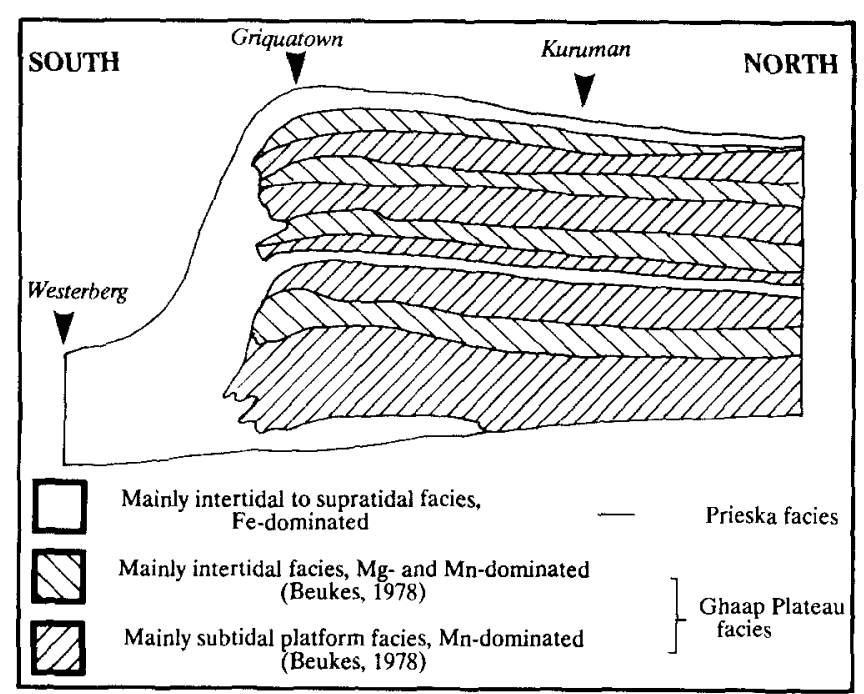

Fig. 12. Simplified cross-section through the Ghaap Group carbonates from the north to the south (after Beukes, 1978). The Fe-dominated, predominantly intertidal to supratidal facies (Prieska facles) was interpreted by Beukes, 1978 as basinal sediments. The re-interpretation implies that the transgressions progressed from north to south and each transgression was followed by regression, that resulted in shallowing upward mega-cycles

described the Prieska facies and the Gamohaan Formation as Fe-dominated whereas the Ghaap facies were Mn and Mgdominated (Fig. 12). Eriksson et al. (1976) assumed that sedimentation of the Transvaal Supergroup took place in an epeiric sea during a time when the atomosphere was oxygen deficient and richer in $\mathrm{CO}_{2}$ than at present. From solubility graphs they assumed that Iron carbonates would precipitate first with increasing $\mathrm{pH}$, followed by $\mathrm{Fe}-\mathrm{Ca}$ and $\mathrm{Fe}-\mathrm{Ca}-\mathrm{Mn}$ carbonates with increasing $\mathrm{pH}$ and decreasing $\mathrm{Fe}$ in solution. Eriksson et al. (1976) consider these predicted geochemical facies to be represented in the northern Cape by the BIF, limestone with Fe-rich dolomites and subtidal Fe-poor carbonates respectively. Eriksson et al. (1976) also discussed the influence of meteoric waters as pH-lowering agents, leading to recrystallization, diagenetic silicification and dolomitization. Danielson (1990) investigated the REE chemistry of the different formations and lithofacies of the Ghaap Group north of Griquatown Fault Zone and concluded that the Monteville and Gamohaan Formations, representing the Prieska facies in this area, have REE patterns typical for marine water at shallow depth. The light gray dolomites and limestones with stratified stromatolites and laminoid fenestrae fabric and the net-like fenestrae dolomite were found to have REE patterns influenced by sea water - fresh water mixing or by axidation of organic materlal. Our interpretation of the Nouga Formation sup- ports the model of Eriksson et al. (1976) and the findings by Danielson (1990). Noteworthy is the fact that some authors discussed a similar Fe-Mn behaviour for oxidizing conditions. For instance, Gatrall et al. (1972) interpreted the high Fe-Mn ratio in Jurassic tronstones and limonite concretions as an effect of river drainage. According to these authors, because of its tendency to oxidation, Iron is deposited in shelf regions while manganese is transported towards the pelagic oceans. Consequently ferromanganese nodules characterize more open sea deposits than the limonitic Jurassic "snuff boxes" of southern England.

The Griqualand West sedimentary basin was located on the craton and no evidence has been found for its southern connection to oceanic realms. We therefore assume that the Lower Proterozoic Kaapvaal Craton extended further to the south of its present boundaries as suggested by Altermann and Halbich (1990). The non-palinspastic paleogeography shows the presence of intertidal to supratidal flats in the Prieska area; intertidal to supratidal flats were also reported from the vicinity of Vryburg (NE of Kuruman) by Truswell and Eriksson (1973). Subtidal conditions are best developed around the Kuruman to Griquatown Fault Zone (Fig. 1). The area between Kuruman and Griquatown must therefore represent the deepest part of the Griqualand West sedimentary basin during the deposition of the Ghaap Group.

The Griquatown Fault may thus be considered to be a synsedimentary normal fault, separating slowly subsiding tidal flats in the south from rapidly subsiding area in the north. As a result, more open marine sediments with well developed subtidal environments and a greater thickness of the sediments accumulated in the north. Beukes (1978; 1980a) proposed a more rapid subsidence and development of basinal facies south of the Griquatown Fault. Altermann and Halbich (1990) interpreted the Griquatown Fault as a thrust. repeatedly reacttvated during the tectogenesis of the southwestern Kaapvaal Craton. In the case of a synsedimentary fault, it is difficult to explain why the thickness of the carbonates south of this zone rapidly decreases, whereas the thickness of BIF rapidly increases, when one assumes coninuous subsidence during both sedimentation periods. Altermann and Halbich (1990) attributed the increasing thickness of BIF sediments to folding and thrusting that affected them. The same can be expected for the Ghaap plateau Dolomite Formation. In fact, in the Debeerskloof region thrusts were found also in the Ghaap carbonates (Altermann and Halbich (1990), where they invert the entire stratigraphy of the Transvaal Supergroup. 
Acknowledgements - We are grateful to the CSIR for providing the grants to undertake these investigations, to Prof. I. W. Halbich and Drs. U. E. Horstmann and J. P. Le Roux for helping measure some of the sections and with many discussions, and last but not least to Messrs. H. Bertram and D. Hendrikse who prepared the thin sections.

\section{REFERENCES}

Aigner, T. 1985. Storm depositional systems. Lecture Notes in Earth Sciences. 3. Springer-Verlag. Berlin. 174 pp.

Aitken, J. D. 1967. Classification and environmental significance of cryptalgal limestones and dolomites, with illustrations from the Cambrian and Ordovician of Southwestern Alberta. Jour. Sediment. Petrol., 37, 1163-1178.

Altermann, W. and Halbich, I. W. 1990. Thrusting. folding and stratigraphy of the Ghaap Group along the south-western margin of the Kaapvaal Craton. J. Geol. Soc. South Africa, 83/4, 553-556.

Armstrong, R. A., Compston, W., Retief, E. A and Welke, H. J. 1986. Ages and isotopic evolution of the Ventersdorp volcanics. Abstracts Geocongress '86, Geol. Soc. South Africa, Johannesssburg.

Awramik, S. M. 1971. Precambrian columnar stromatolites diversity: reflection of metazoan appearance. Sclence, 174, 825-827.

Beukes, N. J. 1977. Transition from siliciclastic to carbonate sedimentation near the base of the Transvaal Supergroup, northern Cape Province, South Africa. Sed. geol., 18, 201-221.

Beukes, N. J. 1978. Die karbonaatgesteentes en ysterformastes van die Ghaap-Groep van die Transvaal Supergroep in Noord Kaapland. $P h$. D. Thesis. Rand Afridaans University. Johannesburg, 580 pp. (unpubl.)

Beukes, N. J. 1979. Litostratigrafiese onderverdeling van die Schmidtsddrff-Subgroep van die Ghaap-Groep in Noord-Kaapland. Trans. geol. Soc. S. Afr., 82, 313327.

Beukes, N. J. 1980a. Stratigrafie en litofasies van die Campbellrand-Subgroep van die Proterofitiese GhaapGroep, Noord-Kaapland. Trans. geol. Soc. S. Afr., 83, 141-170.

Beukes, N. J. $1980 \mathrm{~b}$. Lithofacies and stratigraphy of the Kuruman and Griquatown Iron Formations, Northern Cape Province, South Africa. Trans. geol Soc. S. Afr., 83, 69-86.

Beukes, N. J. 1983. Paleoenvironmental setting of tron formations in the depositional basin of the Transvaal Supergroup, South Africa. In: Iron-Formation: facts and problems. - Developments in Precambrian geology. (Edited by Trendall, A. F. and Morris, C. C.), 6. Elsevier, pp. 131-210.

Beukes, N. J. 1986. The Transvaal Sequence in Griqualand West. In: Mtneral depostts of Southern Africa, (Edited by Anhaeusser, C. R. and Maske, S.), Geol. Soc. S. Afr., Johannesburg, 819-828 pp.

Beukes, N. J. 1987. Facies relations, depositional environments and diagenesis in a major Early Proterozolc stromatolitic carbonate platform to basinal sequence,
Campbellrand Subgroup, Southern Africa. Sed. Geol. 54, 1-46.

Beukes, N. J. 1989. Sedimentological and geochemical relation-ships between carbonate, iron formation and manganese deposits in the Early Proterozolc Transvaal Supergroup, Griqualand West, South Africa. 28th IGC, abstracts 1-143. Washington.

Beukes, N. J. and Lowe, D. R. 1989. Environmental control on diverse stromatolite morphologies in the $3000 \mathrm{Ma}$ Pongola Supergroup, South Africa. Sedimentology, 36, 383-397.

Black, M. 1933. The algal sediments of Andros Island, Bahamas. R. Soc. Phil. Trans., ser. B., 122, 169-192.

Button, A. 1976. Iron Formation as an end member in carbonate sedimentary cycles in the Transvaal Supergroup, South Africa. Econ. Geol, 71, 193-201. Clendenin, C. W. 1989. Tectonic influence on the evolution of the Early Proterozoic Transvaal Sea, South Africa. Unpubl. dissertation. Univ. Witwatersrand. Johannesburg, 376 pp.

Danielson, A. 1990. REE in the Griqualand-West carbonates - evidence for seawater/fresh water mixing? - Abstracts Geooongress ' 90 , Geological Society of South Africa, Cape Town, 116-118.

Davies, G. R. 1970. Algal laminated sediments, Gladstone embayment, Shark Bay, Western Australia, 169-205. In: Carbonate sedtments and envtronments. Shark Bay, Western Australia (Edited by Logan, B. W., Davies, G. R., Read, J. F. and Cebulski, D. E.), Amer. Assoc. Petrol. Geol., Mem, 13.

Donaldson. J. A. 1976. Paleoecology of Conophyton and associated stromatolites in the Pre-Cambrian Dismal Lakes and Rae Groups, Canada. In: Stromatoltes (Edited by Walter, M. R.). Dev. Sedimentol, 20, 523534.

Dravis, J. J. 1983. Hardened subtidal stromatolites, Bahamas. Science, 219, 385-386.

Eriksson, K. A. 1977. Tidal flat and subtidal sedimentation in the 2250 m.y. Malmani Dolomite, Transvaal, South Africa. Sediment. Geol., 18, 223-244.

Eriksson, K. A. and Truswell, J. F. 1974. Tidal flat associations from a Lower Proterozolc carbonate sequence in South Africa. Sedimentology, 21, 293309.

Eriksson, K. A. Truswell, J. F. and Button, A 1976. Paleoenvironmental and geochemical models from an Early Proterozoic carbonate succession in South Africa. In: Stromatolites (Edited by Walter, M. R.), Dev. Sedimentol, 20, 635-643.

Flágel, E. 1972. Mikrofazielle Untersuchungen in der alpinen Trias. Methoden und Probleme. Mitt. Ges. Geol. Bergbaustud., 21, 9-64.

Flagel, E. 1982. Microfacies analysis of limestones, Springer-Verlag, Berlin. Heidelberg. New York, 633 pp.

Folk, R. L. 1959. Practical petrographic classification of limestones. Amer. Assoc. Petrol. Geol., Bull., 43, 1-38.

Garrett, P. 1970. Phanerozoic stromatolites: Noncompetitive ecologic restriction by grazing and burrowing animals. Science, 169, 171-173.

Gatrall, M., Jenkyns, H. C. and Parsons, C. F. 1972. Limonitic concretions from the European Jurassic, with particular reference to the "snuff-boxes" of southern England. Sedimentology, 18, 79-103. 
Ginsburg, R. N. 1955. Recent stromatolitic sediments from south Florida. J. Paleont. 19, 723.

Hardie, L. A. 1977. Sedimentation on the modern carbonate tidal flats of northwest Andros Island, Bahamas. Baltimore, The Johns Hopkins Untversity Press. The Johns Hopktins Universtty Studies in Geology. 22, 202 pp.

Harris, L. D. 1958. Syngenetic chert in the Middle Ordovician Hardy Creek Limestone of Southwest Virglnia. J. Sed. Petrol, 28/2, 205-208.

Hoffiman, P. 1974. Shallow and deep water stromatolites in Lower Proterozoic Platform- to basin-facies change, Great Slave Lake, Canada. AAPG Bull, 58, 856867.

Hoffman, P. 1976. Environmental dtversity of Middle Pre-Cambrian stromatolites. In: Stromatolites (Edited by Walter, M. R.), Dev. Sedimentol, 20, 599-611.

Hofmann, H. J. 1969. Stromatolites from the Proterozoic Animikie and Sibley Groups, Ontarlo. Geol. Survey Canada, Paper, 68-69, 77 pp.

Irwin, M. L. 1965. General Theory of epelric clear water sedimentation. Bull. Am. Assoc. Pet. geol, 49, 445459.

James, N. P. 1980. Shallowing upward sequences in carbonates. In: Factes Models. (Edited by Walker, $R$. G.), Geosctence Canda, Reprint Series 1, 109-120.

Kendall, C. G. St. C. and Skipwith Sir, P. A. D'E. 1969. Holocene shallow water carbonate and evaporite sediments of Khor el Bazam. Abu Dabi, Southwest Persian Gulf. AAPG Bull., 53/4, 841-869.

Klein, C., Beukes, N. J. and Schopf, J. W. 1987. Flamentous microfossils in the early Proterozoic Transvaal Supergroup: Their morphology, significance, and paleoenvironmental setting. Precambrian Research, 36, 81-94.

Logan, B. W. 1961. Cryptozoon and associated stromatolites from the Recent, Shark Bay, Western Australia. J. Geol, 69, 517-133.

Logan, B. W. Rezak, R. and Ginsburg. R. N. 1964. Classification and environmental significance of algal stromatolites. J. Geol. 72, 68-83.

Logan, B. W., Hoffman, P. and Gebelein, C. D. 1974. Algal mats, cryptalgal fabrics, and structures, Hamelin Pool, Western Australla, In: Euolution and diagenesis of Quarternary carbonate sequences, Shark Bay. Western Australia (Edited by Logan, B. W., Read, J. F., Hagan, G. M., Hoffman, P., Brown, R. G., Woods, P. J. and Gebelein, C. D.), Amer. Assoc. Petrol. Geol., Mem. 22, 140-194.

Mawson, D. 1929. Some South Australian limestones in process of formation. Guart. J. Geol. Soc., 85, 613-623.

McIllreath, I. A. and James, N. P. 1980. Carbonate slopes. In: Factes Models (Edited by Walker, R. G.), Geoscience Canada, Reprint Serles 1, 133-145.

Miller, J. 1988. Microscopical techniques: Slices, slides, stains and peels. In: Techniques in sedimentology (Edited by Tucker, M.), Blackwell Sctentific Publications, 86-107.

Monty, C. L. V. 1976. The origin and development of cryptalgal fabrics, In: Stromatolites (Edited by Walter, M. R.), Dev. Sedimentol., 20, 193-249.

Peryt, T. M. 1977. Environmental significance of foraminiferal-algal oncolites. In: Fossil Algae (Edited by Flugel, E.), Springer Verlag Berlin. 61-65.

SACS - South African Committee for Stratigraphy, 1980. Stratigraphy of South Africa. Part 1 (Comp. L. E. Kent). Litho-stratigraphy of the Republic of South Africa, South West Africa/Namibla, and the Republics of Bophuthatswana. Transkel and Venda. Handbook geol. Surv. S. Afr., 8, 690 pp.

Shinn, A. E. 1986. Modern carbonate tidal flats: Their diagnoistic features. In: Hardie, L. A. and Shinn, E. A. (Editors), Carbonate depositional environments. Modern and ancient. Part 3: Tidal flats. Colorado School of Mines Quarterly, 81/1, 17-36.

Smoot, J. P. 1983. Depositional subenvironments in an arid closed basin; the Wilkins Peak Member of the Green River Formation (Eocene), Wyoming, U. S. A. Sedimentology, 30, 801-827.

Truswell, J. F. and Eriksson, K. A. 1972. The morphology of stromatolites from the Malmani Dolomite northwest of Johannesburg. South Africa. Trans. geol. Soc. S. Afr., 75, 99-110.

Truswell, J. F. and Eriksson, K. A. 1973. Stromatolitic associations and their paleoenvironmental signiflcance: A re-appraisal of a lower Proterozoic locallty from the northern Cape Province, South Africa. Sediment. Geol, 10, 1-23.

Van Straaten, L. M. J. U. 1951. Longitudinal ripple marks in mud and sand. J. Sed. Petrol. 21, 47-54.

Visser, J. N. J. and Grobler, N. J. 1972. The transition beds of the Dolomite Series in the Northern Cape Province. Trans. geol. Soc. S. Afr., 75, 265-274.

Walraven, F., Burger, A. J. and Allsopp, H. L. 1982. Summary of age determinations carried out during the perlod April 1980 to March 1981. Annals geol. Surv. S. Afr., 16, 107-114.

Walter, M. R. 1989. Major features in record of Proterozolc stromatolites. 28. IGC, Abstracts, 3-318, Washington.

Wilson, J. L. 1975. Carbonate facies in geologic history, Springer-Verlag. Berlin. Heldelberg, New York, 471 pp.

Young, R. B. 1928. Pressure phenomena in the dolomitic limestones of the Campbell Rand Series in Griqualand West. Trans. geol. Soc. S. Afr., 31, 157-165.

Young, R. B. 1932. The occurrence of stromatolitic or algal limestones in the Campbell Rand Serles, Griqualand West. Trans. geol. Soc. S. Afr., 36, 29-36.

Young, R. B. 1933. Conditions of the deposition of the Dolomite Series. Trans. geol. Soc. S. Afr., 36, 121-135.

Young, R. B. 1934. A comparison of certain stromatolitic rocks in the Dolomite Series of South Africa, with modern algal sediments in the Bahamas. Trans. geol. Soc. S. Afr.. 37, 153-162.

Young, R. B. 1935. A comparison of certain stromatolitic rocks in the Dolomite series of South Africa with marine algal sediments in the Bahamas. Trans. geol. Soc. S. Afr., 37, 153-162.

Young, R. B. 1945. Nodular bodies in the Dolmite Serles. Trans. geol. Soc. S. Afr., 48, 43-50.

Young, R. B. and Mendelssohn, E. 1948. Domed algal growths in the Dolomite Series of South Africa, with associated fossil remains. Trans. geol. Soc. S. Afr., $\mathbf{6 1}$, 53-65. 